\title{
Verb doubling in Mandarin Chinese
}

\author{
Lisa Lai-Shen Cheng • Luis Vicente
}

Received: 6 July 2010/Accepted: 21 April 2012/Published online: 21 August 2012

(C) The Author(s) 2012. This article is published with open access at Springerlink.com

\begin{abstract}
This article examines two so-far-understudied verb doubling constructions in Mandarin Chinese, viz., verb doubling clefts and verb doubling lian...dou. We show that these constructions have the same internal syntax as regular clefts and lian...dou sentences, the doubling effect being epiphenomenal; therefore, we classify them as subtypes of the general cleft and lian...dou constructions, respectively, rather than as independent constructions. Additionally, we also show that, as in many other languages with comparable constructions, the two instances of the verb are part of a single movement chain, which has the peculiarity of allowing Spell-Out of more than one link.
\end{abstract}

Keywords Mandarin Chinese - Verb doubling - Verb movement . Cleft $\cdot$ lian...dou

\section{Introduction}

The goal of this paper is to investigate two little-studied variants of two focus constructions in Mandarin Chinese, namely, clefts and lián...dōu sentences (the latter construction being semantically equivalent to the English focus particle even). As an initial point of reference, consider the following two paradigmatic examples of these constructions, where focus is marked with $[\mathrm{F}]$.

\footnotetext{
L. L.-S. Cheng $(\bowtie)$

Department of Linguistics, Leiden University, Van Wijkplaats 4 (Building 1166), P.O. Box 9515, 2300 RA Leiden, The Netherlands

e-mail: 1.1.cheng@hum.leidenuniv.nl

L. Vicente

Department Linguistik, Universität Potsdam, Campus Golm, Haus 14, Karl-Liebknecht-Straße 24-25, 14776 Golm, Germany

e-mail: vicente@uni-potsdam.de
} 
(1) Cleft sentence

Zhè-běn shū, shì [Ftā] kàn, bú shì wǒ kàn.

this-CL book COP he read NEG COP I read

'(As for) this book, it is he who is going to read it, not me.'

(2) lián...dōu sentence

Tā lián [F zhè-běn shū] dōu kàn-wán-le.

he LIAN this-CL book DOU read-finish-PERF

'He finished reading even this book.'

In both (1) and (2), the focalized constituent is a nominal phrase. Our interest here lies in the variants exemplified in (3) and (4) below, where the focus is not a nominal but rather a verb. For obvious reasons, we refer to these variants as verb doubling clefts and verb doubling lián...dōu sentences. As these labels make clear, the difference between these variants is not just the category of the focus-in addition to this, the verbal variants exhibit a doubling effect that is obligatorily absent from their nominal counterparts. Throughout this paper, we use boldface to highlight the two instances of the verb.

(3) Verb doubling cleft

Chī, wǒ shì [F chī-guò] le, búguò...

eat I COP eat-EXP PERF but

'As for eating, I have (indeed) eaten, but...'

(4) Verb doubling lián...dōu

lián [ ${ }_{F}$ kàn] tā dōu bú kàn

LIAN look he DOU not look

'As for looking, he didn't even look.'

Verb doubling clefts and verb doubling lián...dōu have received very little attention in the literature; as far as we know, only Liu (2004) ${ }^{1}$ and Constant and Gu (2008) offer analyses with some level of insight (see also Paris $(1979,1998)$ ). ${ }^{2}$ Therefore, our primary goal in this paper is to close this gap by developing an explicit syntax

${ }^{1}$ In Liu (2004), there are many examples of what he called "identical topics", and some of these appear on the surface to be non-verbal. However, many are indeed predicates (albeit nominal), as in (1):

(i) tā érzi cōngmíng dào tǐng cōngmíng, jùshì tài cūxīn (= Liu (2004, ex. (3)))

he son smart unexpectedly quite smart but too careless

'Talking about smart, his son is smart unexpectedly indeed but is too careless.'

In this paper, we restrict our attention to verbal predicates.

2 Paris $(1979,1998)$ lists a couple of examples with a verbal element after lián. However, she considers these as nominalized verbs, basically because these verbal elements do not have any aspectual marking. She also argues against a movement account of lián...dōu sentences. See Shyu (1995) for arguments for a movement analysis for lián...dōu sentences. 
for both constructions. We will not focus upon the most notable surface feature of these constructions, i.e., the doubling effect. We will take this effect as a given and only offer some remarks in Sect. 5. For the most part, we will focus our attention on the following two questions.

1. Are verb doubling clefts and verb doubling lián...dōu sentences simply subtypes of the cleft and lián...dōu constructions, or should they be treated as completely different constructions?

2. What is the relation between the two verbs?

As for the first question, we will show that, abstracting away from the doubling effect, there is no significant syntactic difference between verb doubling clefts and verb doubling lián...dōu sentences and their non-verbal counterparts. The verbal and non-verbal variants are subtypes of the general cleft and lián...dōu constructions. As for the second question, we will show that the two verbs stand in an A-bar movement relation; more specifically, we will show that, as in comparable constructions in many other languages, the verbs are links of one and the same A-bar movement chain, which has the exceptional property of allowing pronunciation of more than one of its links.

We will also use the second conclusion to support some recent ideas about the nature of verb movement. The fact that a bare verb is undergoing A-bar movement would appear, at first sight, to point towards an analysis in terms of remnant VP movement, on a par with analyses of comparable phenomena in other languages (e.g., Russian; see Abels 2001). However, we will show that an analysis along these lines is untenable due to the fact that Chinese lacks the means to create remnant VPs in a productive way. Our alternative, following proposals for languages exhibiting the same conundrum (cf., Landau 2006; Vicente 2009), is that a bare verbal head can undergo long-distance A-bar movement. This is, in essence, an adaptation of Koopman's (1984) analysis of similar data in Vata.

In order to attain these goals, we proceed as follows. In Sect. 2, we describe several points of parallelism between the syntax of verb doubling and regular clefts and conclude that, despite some minor differences, they represent two instances of one and the same construction. In Sect. 3, we repeat the same exercise (with the same conclusions) for verb doubling and regular lián...dōu sentences. In Sect. 4, we turn to the question of verb movement; there, we show that Mandarin lacks the means to create remnant VPs. Therefore, the movement we observe must be movement of a bare verbal head, without any prerequisites of object movement out of VP. Finally, in Sect. 5, we offer a few brief remarks about the difficulties that current approaches to doubling effects encounter with these two constructions.

\section{The internal syntax of verb doubling clefts}

In this section, we cover various aspects of verb doubling clefts. We begin by showing in Sect. 2.1 that they have the same properties as regular nominal clefts. Next, in Sect. 2.2, we show that the relation between the two verbs is one of movement, i.e., the verbs are links of one single movement chain. Finally, in Sect. 
2.3, we discuss and propose a solution to some difficulties posed by the movement analysis of clefts.

\subsection{Basic properties of clefts}

In this paper we follow the analysis of cleft sentences laid out in Cheng (2008), which she refers to as bare 'shì' sentences. Shì is the copular verb, which Cheng claims takes a small clause (SC) with pro predicate (5a). This pro predicate undergoes predicate raising to the left of the copular verb (5b), making bare shi sentences inverse predication structures, i.e., structurally equivalent to English it is $x$ sentences (cf., Moro 1997; Mikkelsen 2004), with the pro predicate being the counterpart of it. We refer the reader to Cheng's work for a detailed discussion of the syntax of this class of sentences.

(5) Structure of clefts
a. shì [SC [subJect XP] [PRED pro]]
b. $[\text { pro }]_{\mathrm{i}}$ shì $\left[\mathrm{SC}[\right.$ SUBJeCt $\left.\mathrm{XP}] t_{\mathrm{i}}\right]$

The focus of the cleft is the constituent that appears linearly to the immediate right of shi (structurally, the subject of the SC complement of shi). ${ }^{3}$ In addition, various sub-constituents of the SC subject may appear to the left of shì, which Cheng (2008) descriptively refers to as floating shì. These constituents are typically interpreted as topics, which we indicate with $[\mathrm{T}]$, as in $(6 \mathrm{a})$. Note also that, although (6b) places the focus on the verb kàndào 'see', we do not consider this an example of a verb doubling cleft for two reasons: first, there is quite obviously no verb doubling; second, the interpretation of (6b) differs from that of a verb doubling cleft, as we discuss immediately below.

(6) a. $[\mathrm{T}$

$\begin{array}{lllll}\text { Zhāngsān] } & \text { shì [F zuótiān] } & \text { kàndào } & \text { Wáng } & \text { xiǎojiě } \\ \text { Zhangsan } & \text { COP yesterday } & \text { see } & \text { Wang } & \text { Ms. } \\ \text { (bú shì } & \text { qiántiān). } & & & \\ \text { not coP } & \text { day.before.yesterday } & & & \end{array}$

'It is yesterday that Zhangsan saw Ms. Wang

(and not the day before yesterday).'

b. [T Zhāngsān] [T Zuótiān] shì [F kàndào] Wáng

Zhangsan yesterday COP see Wang

xiăojiě (bú shì gēn tā shuō-guò huà.

Ms. not COP with her talk.EXP word

'It is seeing Ms. Wang that Zhangsan did yesterday (and not talking to her).'

\footnotetext{
${ }^{3}$ In typical nominal cleft sentences, it is usually the DP immediately to the right of shi which is focused. In the verbal cleft cases, it is possible that something intervenes between shi and the verb, as we see from sentences in (9). In such cases, it is actually the whole VP which is focused.
} 
Example (7) shows that the element marked for contrastive focus needs to be adjacent to shì.

(7)

\begin{tabular}{lclll} 
*Shì & Zhāngsān & [F & míngtiān $]$ dào \\
COP & Zhangsan & \multicolumn{2}{c}{ tomorrow to } \\
Nǐuyue & qù, bú & shì hòutiān \\
New York & go not & cop the.day.after.tomorrow
\end{tabular}

Intended: 'It is tomorrow that Zhangsan goes to New York, not the day after tomorrow.'

Verb doubling clefts exhibit the same distribution of topic and focus. ${ }^{4}$ The first instance of the verb, being to the left of shi, is interpreted as a topic; similarly, the second instance of the verb, which follows shi, is interpreted as a (part of the) focus. Consider example (3) again, repeated here as (8A). We use boldface to highlight the doubled verb.

(8) Verb doubling clefts

Q: Nĩ chī-guò fàn měiyǒu?

you eat-EXP rice not.have

'Have you eaten already?'

A: [ $\left.{ }_{\mathrm{T}} \mathbf{C h \overline { ̄ }}\right],\left[_{\mathrm{T}} \mathrm{wō}\right]$ shì [ ${ }_{\mathrm{F}}$ chī-guò], búguò...

eat I COP eat-EXP but

'As for eating, I have indeed eaten, but...'

It is important to note that the focalized instance of $c h \bar{\imath}$ 'eat' is not interpreted as a contrastive focus (compare to kàndào 'see' in (6b) above, which is a contrastive focus); rather, it is interpreted as a verum focus, that is, as affirming the truth of the proposition (see Höhle 1992 and Krifka 2007). We indicate this shade of meaning through the use of the modifier indeed in the translation. This seems to be a general property of verb doubling in cleft-like structures in other languages (cf., Bastos 2001 for Brazilian Portuguese, Vicente 2009 for Spanish). ${ }^{5}$ Additionally, as we also

\footnotetext{
4 A reviewer points out that when there are multiple topics including also a verbal topic, an ordering restriction obtains. For instance, in (i), the verbal topic cannot precede jiăozi 'dumpling'.

(i) jiǎozi, chī, wǒ shì chī-guò,

dumpling eat $\mathrm{I} \quad \mathrm{COP}$ eat-EXP

'As for dumpling, eating, I have (indeed) eaten, ...'

Such a restriction is not surprising when it comes to multiple topics since topics are not all interpreted the same (see for example Frascarelli and Hinterhölzl 2007). In the case of verbal topics in the verbal clefts, note that the verbal topic is linked with the focused verb following the copula, and this verb is interpreted as verum focus (see below). So this topic is typically more contrastive. In the case of (i) above, the first topic is probably a discourse topic, which naturally precedes a contrastive topic.

5 Bastos (2001, p. 52ff) provides an explanation for this effect. Our interpretation of it is as follows: the leftmost instance of the verb, being a topic, highlights old, presupposed information (by the definition of topic). The comment on this topic contains a focus on the second instance of the verb. This focus cannot
} 
see in other languages with similar constructions (see works just cited), Mandarin verb doubling clefts trigger an adversative implicature, which can be lexicalized by appending búguò 'but' to the cleft. This implicature conveys the meaning that, while the proposition focused by the cleft is true, some additional contextual factors need to be taken into account (for instance, in the case of (8A), this might be that, while the speaker did eat, he enjoy the meal, or he didn't find it filling).

Consider the sentences in (9), which illustrate that to achieve verum focus, the verb does not have to be adjacent to shì; adverbs such as yíding 'certainly', and tiāntiān 'every day' can intervene between shì and the verb.
a. Chī, wǒ shì xiăng chī, ... eat, I COP want eat
'As for eating, I do want to eat; but ...'
b. Chī, wǒ shì yídìng huì chī, ... eat, I COP certainly will eat
'As for eating, I will certainly eat; but ...'
c. Chī, wǒ shì tiāntiān chī, ...
eat, I COP daily eat
'As for eating, I do eat every day; but ...'

$(10 \mathrm{a}, \mathrm{b})$ illustrate that the intervening materials cannot be a subject (e.g., wǒ 'I') or a speaker-oriented high adverb such as xiănrán 'obviously' (which we assume to be above the IP-level).

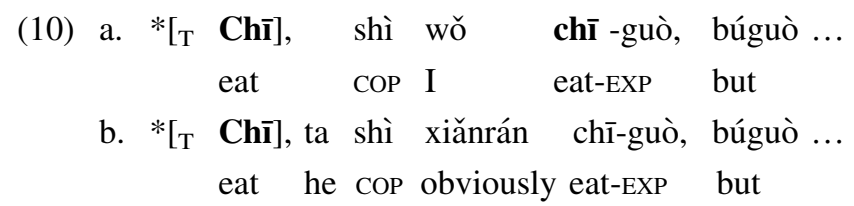

Based on the contrast between (9) and (10), we conclude that in the case of verum focus, the subject of the SC must be a $v \mathrm{P} .{ }^{6}$ Why should this be so? Verum focus is focus on the truth of the proposition (e.g., in our baseline example (3), the focal alternative to "eating" is "not eating", rather than "drinking", "walking", etc.). We propose that this requires focalizing not the lexical verb itself but rather the event argument, which we assume is located in $v$ (Kratzer 1996). The upper instance of the verb establishes the proposition as a topic, on which a comment can be made; by focalizing the event argument inside the comment, we are asserting that the event in

\footnotetext{
Footnote 5 continued

be either new information focus or contrastive/corrective focus because these two kinds of foci add new information to the Common Ground. Rather, what this focus does is to (re)assert presupposed information. Since the information in question is an event (on the assumption that verbs contain the event argument of the sentence), the result is a verum focus reading, i.e., an assertion of the truth of the event described by the clause.

6 This entails that hui 'will' or the adverb yíding 'certainly' is generated at the $v \mathrm{P}$ level.
} 
question did take place, i.e., a more verbose paraphrase of (3) would be "as for the event of eating, that event did happen (as opposed to not happening)". ?

\subsection{Movement effects in verb doubling clefts}

In this section, we show that the relation between the two verbs in verb doubling clefts is one of movement. More specifically, we show that the two verbs constitute the head and the tail of an A-bar movement chain, which has the exceptional property of allowing pronunciation of more than one of its links. In this respect, Mandarin verb doubling clefts are parallel to similar structures in other languages (e.g., Russian, Hebrew, Spanish, Hungarian, Yiddish, Nupe, etc.), where the results of various tests also point towards a movement relation.

\subsubsection{Locality constraints}

If the two verbs of a verb doubling cleft stand in an A-bar movement relation, then we would expect them to be sensitive to the presence of intervening island boundaries. Here we show that this prediction is correct. Let us start by considering a baseline sentence without any intervening island boundaries, which shows that, in principle, it is possible for the two verbs to be separated by an arbitrary number of clause boundaries.

Q: Zhāngsān kàn-guò zhè-bù diànyı̌ng ma? Zhangsan see-EXP this-CL movie Q?

'Has Zhangsan seen this movie?'

A: Kàn, wǒ xiāngxìn tā shì [F kàn-guò], búguò... see I believe he COP see-EXP but

'As for seeing, I believe he has indeed seen it, but...'

However, this dependency may not span an island boundary. We illustrate this restriction below with adjunct islands and complex NP islands. ${ }^{8}$

\footnotetext{
7 Cheng (2008) claims that the subject of the small clause under the copular verb is a CP since the whole sentence (including elements in the SpecCP) can be in the scope of contrastive focus. If the analysis of verb doubling clefts is correct in that what is being focalized is the $v \mathrm{P}$, it implies that the subject of the small clause can vary in terms of size, depending on what is being focalized.

${ }^{8}$ It is important not to compare these sentences with cases in which there is no verb topicalization, the reason being that in typical bare-shi clefts, the interpretation obtained is a contrast focus interpretation of the item immediately to the right of shi. In the case of verb doubling clefts, the topicalization of the verb is essential to the verum focus interpretation. For the example in (12a), it is important to compare it with (i) below, where the verum focus rests upon the main clause.
}

(i) chī, [wǒ huí jiā y̌̃qián] tā shì y̌ìīng chī-guò le, búguò ...

eat I return home before he COP already eat-EXP SFP, but

'As for eat"ing, he already ate before I got home, but ...' 


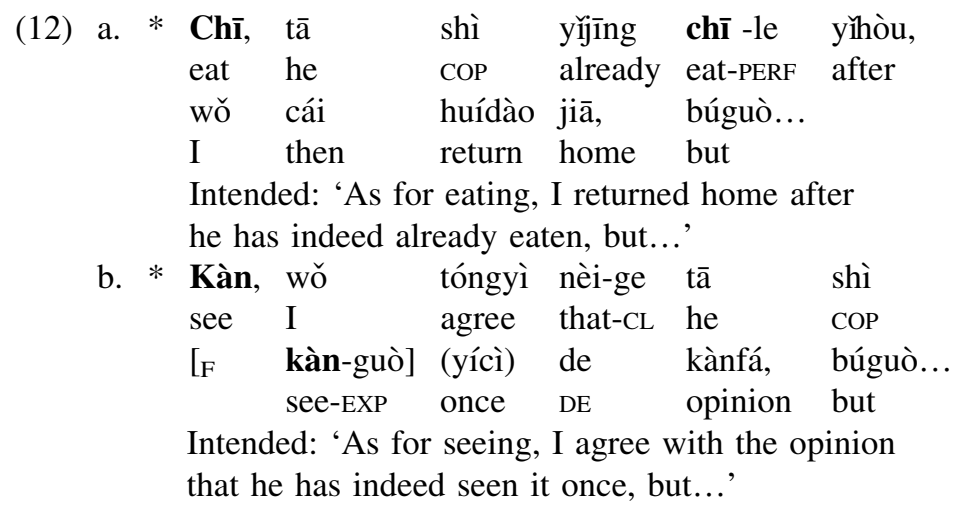

Therefore, we conclude that the dependency between the two verbs in a verb doubling cleft is mediated by an A-bar chain.

\subsubsection{Lexical identity effects}

In the previous subsection, we have shown that the two instances of the verb are linked by a movement relation. Nonetheless, there are still two possibilities about what is moving. One of the options is that it is the verb itself that moves, and the resulting chain is exceptional in that more than one link is spelled out [as suggested for several other languages with parallel constructions, see, amongst others, Abels (2001) for Russian, Landau (2006) for Hebrew, Kandybowicz (2006) for Nupe, or Vicente (2009) for Spanish]. The other option is that what moves is a null operator, which licenses merger of the leftmost instance of the verb as a topic (cf., Cable 2004 for Yiddish).

Verb movement plus spell out of multiple chain links

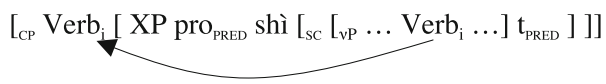

(14) Null operator movement plus merger of verb as a topic 9

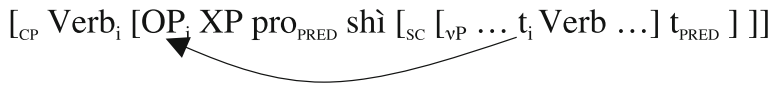

\footnotetext{
${ }^{9}$ Given that we will eventually dismiss the derivation in (14), the question of the base position of the operator is a moot one. However, we have chosen to place it right before the verb, following a similar proposal by Hoge (1998) for Yiddish. Specifically, Hoge proposes that Yiddish verb doubling involves two stacked VPs, each containing an independent verb; then, the verb heading the upper VP moves to a topic position. The derivation in (14) assumes this syntax with the only difference of replacing Hoge's upper verb with a phonetically null operator.
} 
Here we present an argument in favor of derivation (13) on the basis of lexical identity effects. The following example shows that both instances of the verb need to be lexically identical; it is not possible for one of them to further specify the other.

(15) Lack of lexical identity in verb doubling clefts

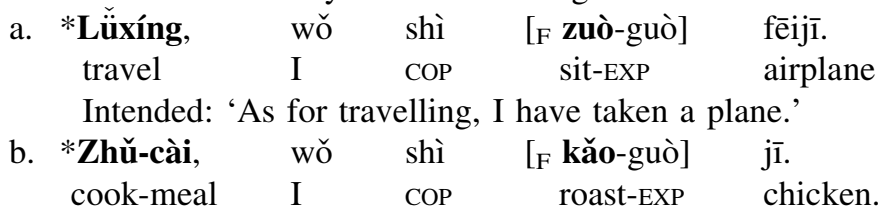

Intended: 'As for cooking a meal, I have indeed roasted chicken.'

This restriction is unexpected, given that Mandarin allows aboutness topics where the meaning of the topic can be further restricted by a constituent within the comment, as in (16).

(16) Yiě-shēng dòng-wù, wǒ zuì x̌̌-huān shīzi.

wild animal I most like lion

'As for wild animals, I like lions the best.'

Here we follow Cable (2004) and Vicente (2007) in analyzing lexical identity effects as a consequence of movement. In other words, if both instances of the verb in verb doubling clefts are links of one and the same movement chain, then the lexical identity effect follows directly from the copy theory of movement. We can support this analysis by noting that other lexical identity effects also arise in other languages (e.g., Spanish and Hungarian, cf. Vicente 2007) where there is independent evidence that similar constructions are derived via movement.

(17) Lexical identity effect in Spanish and Hungarian

a. *Cocinar, pro he asado un pollo. [Spanish] cook have.1sG roasted a chicken

'As for cooking, I have indeed roasted a chicken.'

b. *Utazni, repültem New-York-ba.

[Hungarian] travel flew.1sG New.York.into

'As for traveling, I flew to New York'

Conversely, languages where no movement is involved (e.g., Yiddish, cf., Cable (2004)) do not enforce lexical identity.

(18) No lexical identity effect in Yiddish

Forn, bin ikh gefloygn keyn Nyu-York.

travel am I flown to New York

'As for travelling, I have indeed flown to New York.'

Consequently, we conclude that the correct derivation for Mandarin verb doubling clefts is as in (13): a verbal constituent undergoes A-bar movement out of the focus 
position and into a topic position, and the resulting chain is exceptional in that more than one chain link is spelled out. ${ }^{10}$

\subsection{Movement asymmetries in verb doubling and regular clefts}

The previous subsection has shown that the two verbs in a verb doubling cleft are links of the same A-bar movement chain. This means, graphically, that a verb doubling cleft like (2) has the following structure.

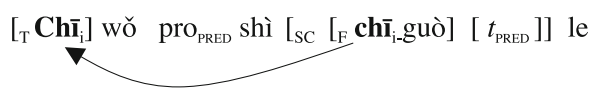

As (19) shows, we are proposing that verb doubling clefts involve movement out of a SC subject. This analysis might seem a priori problematic due to the ban on A-bar extraction of the post-copular subject in inverse predication constructions (see Heycock 1994; Moro 1997; Den Dikken 2006). ${ }^{11}$ Specifically in order to circumvent this difficulty, previous analyses of Mandarin clefts (Huang 1988; Cheng 2008) have assumed that topicalized constituents are base-generated in their surface position. As an illustration, consider the analysis of (6a) (repeated below as (20)) in Cheng (2008), where the topic Zhāngsān binds a pro in the SC subject, as illustrated in (21).

\footnotetext{
${ }^{10}$ We appreciate that moving a constituent from a focus position to a topic position might look contrived at first sight. However, this specific sequence of movements is attested in other languages. For instance, Grohmann (2005) provides the following German example.
}

(i) Diesen Frosch, den hat die Prinzessin gestern geküßt. this.ACC frog it.ACC has the princess yesterday kissed 'As for this frog, the princess kissed it yesterday.'

Various things are notable in this example. First, the resumptive pronoun den appears in SpecCP (e.g., it counts as "first" for the calculation of verb second), which is the position typically reserved for focalized phrases; on the other hand, the dislocated phrase diesen Frosch appears in a topic position. Second, Grohmann provides ample evidence that diesen Frosch and den are related by movement (e.g., case matching, reconstruction, island sensitivity), as we do here for the Mandarin verb doubling examples. Grohmann's proposal is that diesen Frosch moves from its thematic position to SpecCP and then to a topic position; for independent reasons, the copy left in SpecCP is spelled out as a pronoun rather than as a full DP or a gap. Beyond German, Lipták and Vicente (2009) make essentially the same case for a similar construction in Hungarian. These examples show that, in principle, nothing forbids movement from a focus position into a topic position. We submit that the difference between Mandarin and German/ Hungarian lies exclusively at the PF level, namely, Mandarin spells out the lower copy in full whereas German and Hungarian spell it out as a pronoun.

11 In the inverse predication sentence in (i), the post-copular noun phrase the photograph of is the subject of the small clause, and the cause of the riot is the raised predicate. (i) shows that extraction out of the noun phrase yields ungrammaticality.

(i) *What do you think the cause of the riot may have been the photograph of?

The situation is actually a bit more complicated. In the inverse predication cases (like the verbal doubling clefts cases), even the movement of the subject to an A-bar position is restricted (see Den Dikken (2006) for a detailed discussion). 


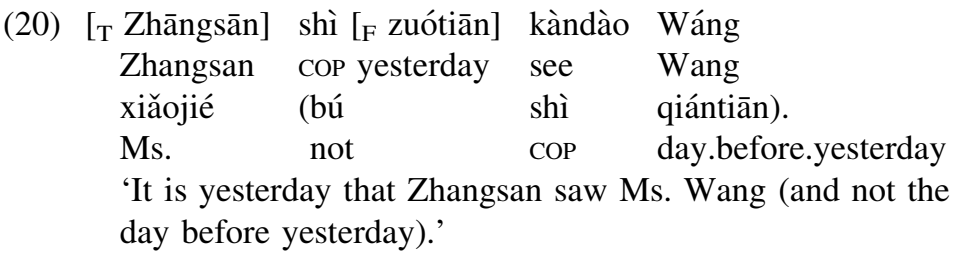

\section{(21) Zhāngsān ${ }_{i}$ pro $_{P R E D}$ shì [sC [pro ${ }_{i}$ zuótiān kàndào Wáng xiǎojié] [ $\left.\left.\mathrm{t}_{\mathrm{PRED}}\right]\right]$}

At this juncture, the question that arises is this: how can we extract a verb out of a SC subject in verb doubling clefts if the same kind of movement gives rise to ungrammaticality otherwise? Note that we cannot say that the lower copy of the verb functions as a kind of resumptive, somehow nullifying the movement violation. If this were true, then we would also expect verb doubling clefts to be island insensitive, contrary to fact (cf., Sect. 2.2.1). Therefore, the solution must lie elsewhere.

In order to understand extraction possibilities from the SC subject, let us first consider examples of bare-shi clefts with wh-phrases (i.e., wh-clefts) in (22).
a. Shì [SC [shéi mǎi-le yī-běn shū] pro $\left.\left._{\mathrm{PRED}}\right]\right]$ ?
COP who buy-PERF one-CL book
'Who is it that bought a book?'
b. Zhāngsān shì $\left[\mathrm{SC} \quad\left[\mathrm{pro}_{\mathrm{i}}\right.\right.$ shěnme shíhòu dào pro $\left.\left._{\mathrm{PRED}}\right]\right]$ ? Zhangsan $\mathrm{COP}$ what time arrive
'What time is it that Zhangsan will arrive?'
c. Zhāngsān shì [sC $\left[\right.$ pro $_{i}$ măi -le shěnme shū] pro $\left.\left._{\mathrm{PRED}}\right]\right]$ ? Zhangsan COP buy-PERF what book
'Which book is it that Zhangsan bought?'

These sentences illustrate three things: (a) the narrow focus can be informational focus on the wh-phrase; (b) even in the case of narrow focus, shi does not have to be linearly adjacent to the focused element (22c); and (c) the wh-phrase can take scope out of the SC since all the cases in (22) yield a matrix question interpretation. If whphrases undergo movement at LF, it means that the extraction out of the SC subject is indeed possible. ${ }^{12}$

Consider now (23), which shows that when the subject Zhāngsān precedes the $w h$-phrase, the sentence becomes ungrammatical (similar to the sentence in (7), where the subject also follows shi and precedes the focused element).

$$
\begin{aligned}
& \text { *Shì [SC [Zhāngsān mǎi -le shěnme] pro } \left.{ }_{\mathrm{PRED}}\right] \text { ? } \\
& \text { COP Zhangsan buy-PERF what } \\
& \text { 'What is it that Zhangsan bought?' }
\end{aligned}
$$

The question rests upon the contrast between (22c) and (23). Cheng (2008) points out that in bare-shì clefts, a non-canonical word order is possible in the SC subject.

\footnotetext{
12 Soh (2005) argues that wh-arguments undergo phrasal movement at LF in Chinese while wh-adverbs undergo feature movement.
} 
In particular, there can be a fronted element, as indicated in (24) (examples adapted from Cheng (2008), ex. 44a,b).
a. Shì zhè-běn shu Zhāngsān méi kàn-guò COP this-CL book Zhangsan not.have read-EXP 'It is this book that Zhangsan hasn't read (not that one).'
b. Shì zuótiān tā méi qù shàngkè COP yesterday he not.have go attend.class 'It is yesterday that he didn't go to class (not other days).'

In $(24 a, b)$, it is the fronted elements that are being focused. Importantly, wh-clefts do not allow a fronted constituent, as shown in (25):
a. *Shì
zhè-běn shū
shéi
măi-le
COP
this-CL book
who
buy-PERF
Intended: 'Who is it that bought THIS BOOK?'
b. *Shì zuótiān tā mǎi -le shěnme shū COP yesterday he buy-PERF what book

Intended: 'What book is it that he bought YESTERDAY?'

We suggest that the ungrammaticality in (7) and (23) as well as (25) rests upon the fact that the left periphery of the subject SC is occupied. That is, when a subject does not appear as a matrix topic, it has also been fronted (within the subject clause, as a focused element). (7) thus has the structure in $(26)^{13}$ :
(26) shì [sc [ ${ }_{\mathrm{CP}}$ Zhāngsān [ ${ }_{\mathrm{CP}}\left[\mathrm{t}_{\mathrm{i}}\right.$ míngtiān dào Nũuyuē qù]]] pro pred $_{\text {] }}$ COP Zhangsan tomorrow to New York go

For a wh-phrase to be able to exit the SC subject, it has to be taken to the left periphery of the SC subject. This can then explain the contrast between (22c) and (23). In particular, (22c) has the structure in (27), with the movement of the whphrase indicated in (27a). If the left periphery of the CP is already occupied by another element (e.g., by a focused subject), the wh-phrase cannot directly undergo movement to the left periphery ((23) is represented in (27b)).

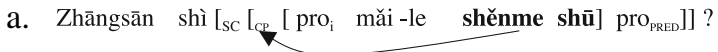
b. *shì [SC $\left[_{\mathrm{CP}}\right.$ Zhāngsān [ $\mathrm{t}_{\mathrm{i}}$ măi -le shěnme $\left.]\right]$ pro $\left.\left.{ }_{\mathrm{PRED}}\right]\right]$ ?

Let us now turn back to the verb doubling clefts. As shown in (28b) (contrasting with (22c), verb doubling clefts cannot contain a wh-phrase.

\footnotetext{
${ }^{13}$ Note that in these cases, the small clause subject is a $\mathrm{CP}$ because this is not a verum focus. As indicated in footnote 7, if our analysis is correct about verum focus (i.e., the verbal doubling cases), then the size of the small clause subject may vary depending on the type of focus.
} 

a. mǎi, tā shì
măi-le
nà-běn
shū,
búguò...
buy he COP
buy-PERF
that-CL
book
but

'As for buying, he indeed bought that book, but ...'

$\begin{array}{llllll}\text { b. *mǎi, } & \text { tā } & \text { shì mǎi-le } & \text { shěnme shū, } & \text { búguò ... } \\ \text { buy } & \text { he } & \text { COP } & \text { buy-PERF } & \text { what book } & \text { but }\end{array}$

Intended: 'As for buying, what is it that he indeed bought? but ...'

We argue that the ungrammaticality is on a par with what we have seen in (7), (23), and (25). In particular, in order for the wh-phrase to take scope in the matrix, it first needs to move to the left periphery of the SC subject (in this case, the $v \mathrm{P}$ ). The fact that (28b) is illicit suggests that the left periphery is occupied. We suggest that when the verb undergoes fronting, it first has to move to the left periphery of the $v \mathrm{P}$. In other words, the presence of the copy of the verb at the left edge of the $v \mathrm{P}$ blocks the movement of the $w h$-phrase at LF. ${ }^{14}$

The use of the left periphery of the $\mathrm{CP}$ as well as the left periphery of the $v \mathrm{P}$ can be due to the phase status of these phrases. In regular clefts, something has to be in the SpecCP, and thus, nothing else can be extracted out of the SC subject. ${ }^{15}$

\subsection{Interim conclusion I}

We have seen in this section that verb doubling clefts and regular clefts are derived from the same syntactic frame, i.e., a copular verb shi taking a SC complement, the predicate of which is a null pro predicate that undergoes predicate inversion. As a consequence of this parallelism, both regular and verb doubling clefts have an identical distribution of topics and foci. On the other hand, the asymmetries between verb doubling and regular clefts that we have discussed are epiphenomenal and do not affect the syntax we are proposing. First, the fact that extraction of the verb out of a SC subject is unproblematic is a consequence of the movement of the verb to the left periphery of the $v \mathrm{P}$; second, the verum focus reading that characterizes verb doubling clefts (as opposed to the plain contrastive focus reading of regular clefts) can be taken to be an inherent property of focus constructions involving verb doubling, given the available typological evidence. Following Bastos (2001), we assume that this particular focus reading arises as a consequence of the fact that the upper copy of the verb is interpreted as a topic.

\section{The internal syntax of verbal lián...dōu sentences}

In this section, we examine verb doubling lián...dōu sentences and reproduce the same conclusions we reached for verb doubling clefts. First, in Sect. 3.1, we show that the verbal and non-verbal counterparts of the lián...dōu construction have nearly identical distribution. In Sect. 3.2, we show that the two verbs are related by A-bar movement and, specifically, that they are links in one single A-bar movement chain.

\footnotetext{
14 There is ample evidence that in situ foci move to a scope position at LF; see Tancredi (1990, 2004), Drubig (1994), Krifka (1996, 2006), Wagner (2006), and references in those works.

15 If the above reasoning is correct, it entails that movement out of the small clause subject is indeed possible.
} 


\subsection{Basic properties of lián...dōu sentences}

As briefly mentioned in the introductory section, the Mandarin lián...dōu construction is semantically similar to English even (see, amongst others, Tsai 1994; Shyu 1995; Hole 2004; Badan 2007, 2008). As an illustration, consider (2) again, repeated here as (29).

(29) lián...dōu sentence

Tā lián [F zhè-běn shū] dōu kàn-wán-le.

he LIAN this-CL book DOU read-finish-PERF

'He finished reading even this book.'

English even functions by picking the entity (or entities) lying at one of the extremes of a scale and asserting that a property holds of that entity as well as of all other nonextreme entities in the scale. In other words, even combines scalarity and additivity. The Chinese lián...dōu construction is equivalent to even because lián and dōu encode these two ingredients. On the one hand, we follow Giannakidou and Cheng (2006), Xiang (2008), and Cheng (2009) in treating $d \bar{o} u$ as a maximality operator, which is adjoined to $v \mathrm{P}$. This provides us with reference to a scalar extreme. On the other hand, lián, which is widely considered to be a focus particle (see, among others, Tsai 1994; Gao 1994; Shyu 2004; Badan 2007), provides us with additivity. In lián...dōu sentences, lián asserts that a certain property holds of the entities at the scalar extreme defined by $d \bar{o} u$. We refer the interested reader to Shyu (1995) and Badan (2007) for a detailed exposition of the semantics of lián...dōu.

The following two examples illustrate three fundamental properties of regular lián...dōu sentences. First, the focused constituent appears immediately to the right of lián and precedes $d \bar{o} u$; second, the presence of lián is optional; third, the [(lián) FOCUS] sequence can be positioned either before or after the subject of the clause.
a. Tā
lián $\mathrm{FF}_{\mathrm{F}}$
zhè-běn
shū] dōu kàn-wán-le.
he
this-CL
book DOU read-finish-PERF
'He finished reading even this book.'
b. (Lián) [F zhè-běn shū], tā dōu kàn-wán-le. LIAN this-CL book he DOU read-finish-PERF
'He finished reading even this book.'

All these properties can be reproduced with verb doubling lián...dōu sentences, as illustrated in (31), suggesting a common syntax with the regular type. As with verb doubling clefts, we use boldface to highlight the two instances of the verb.
a. Tā
(lián) [F kàn] dōu méi
kàn.
he LIAN look DOU not.have look 'He didn't even look.'
b. (Lián) $[\mathrm{F}$ kàn], tā dōu méi kàn. LIAN look he DOU not.have look
'He didn't even look.'

It should be noted that the variation in the position of [(lián) FOCUs] correlates with other distinctions. Firstly, in regular lián...dōu sentences, when [(lián) Focus] is in 
pre-subject position (henceforth initial lián), the presence of both a resumptive pronoun in clause-internal position and the topic marker $a$ is allowed (32a). In contrast, [(lián) FOCUs] in post-subject position (internal lián) is incompatible with either a resumptive pronoun or the topic marker (32b). On the basis of these differences, Shyu (1995) and Badan (2007) argue that initial lián is a contrastive topic whereas internal lián is a simple focus (see Jayaseelan 2001; Butler 2003, and others for theoretical and typological justification of this position). We follow Büring (1997) and Krifka (2007) in assuming that contrastive topic is a subtype of focus, which emphasizes a contrast. ${ }^{16}$

$$
\begin{aligned}
& \text { a. (Lián) Zhāngsān (a), wǒ zuótiān dōu kànjiàn (tā) le. } \\
& \text { LIAN Zhangsan TOP I yesterday DOU see him SFP } \\
& \text { 'Even Zhangsan, I have seen (him) yesterday.' } \\
& \text { b. Wǒ zuótiān (lián) Zhāngsān (*a) dōu kànjiàn (*tā) le. } \\
& \text { I yesterday LIAN Zhangsan TOP DOU see him SFP } \\
& \text { 'I saw even Zhangsan Yesterday.' }
\end{aligned}
$$

Verb doubling lián...dōu illustrates a similar distinction even though it is not possible to use resumptive pronouns to test the verbal counterpart since Mandarin lacks (overt) resumptive pronominal-predicates. As shown in (33), verb doubling lián...dōu sentences pattern together with their regular counterparts in that the initial lián plus verb can be followed by the topic marker $a$, in contrast with the internal lián plus verb sequence. Consequently, we can conclude that the initial and internal versions of verb doubling lián...dōu sentences pattern with the initial and internal versions of regular lián...dōu sentences, and the initial lián sequence obtains a contrastive topic reading.
a. Tā (lián) [ ${ }_{F}$ kàn] (*a) dōu méi kàn.
he LIAN look TOP DOU not.have look 'He didn't even look.'
b. (Lián) [F kàn] (a) tā dōu méi kàn. LIAN look TOP he DOU not.have look 'He didn't even look.'

\footnotetext{
${ }^{16}$ We want to reiterate here that initial lián does not receive a plain topic reading. In Shyu (1995), initial lián has a contrastive topic reading (e.g., Shyu 1995, pp. 126-127 states that initial lián "is a focused topic, which always bears a contrastive interpretation"). The label "contrastive topic" is arguably a misnomer, as the consensus in the literature indicates. Büring (1997) and Krifka (2007) argue that contrastive topics are actually a subtype of focus. Further, both Krifka and Büring note that contrastive topics are only a part of a double focus construction, as the following examples (from Krifka 2007) shows:
}

(i) A. What do your siblings do?

B. $\left[\mathrm{My}[\mathrm{SISter}]_{\text {Focus }}\right]_{\text {Topic }}[\text { studies MEDicine }]_{\text {Focus }}$, and $\left[\mathrm{my}[\text { BROther }]_{\text {Focus }}\right]_{\text {Topic }}$ is [working on a FREIGHT ship $]_{\text {Focus. }}$ 
Second, initial lián allows long-distance construal while internal lián does not, as shown in (34). ${ }^{17}$ Shyu (1995) argues that internal lián focalization is clause-bound, suggesting that the movement of the lián-NP to the post-subject position is more akin to A-movement while the initial lián focalization (as in (34a)) involves A-bar movement.

(34) a. (Lián) zhè-běn shū wǒ y̌̌wéi tā dōu kàn-le.

LIAN this-CL book I think he DOU read-PERF

'Even this book, I thought that he has read.'

b. *Wǒ lián [F zhè-běn shū] yřwéi tā dōu kàn-le.

I LIAN this-CL book think he DOU read-PERF

Intended: 'I thought that he has even read this book.'

This difference is again replicated with verb doubling lián...dōu, as illustrated in (35).

a. (Lián) kàn, wǒ xiāngxìn tā dōu méi làn.
LIAN look I believe he DOU not.have look
'As for looking, I believe that he didn't even look.'
b. *Wǒ lián [F kàn] xiāngxìn tā dōu méi
I Làn.
Intended: 'I believe that he didn't even look.'

Given these parallelisms between the regular and the verb doubling versions of lián...dōu sentences, we reach the same conclusion as we did for clefts in the previous section, namely, both versions have the same underlying syntax, the doubling effect being epiphenomenal (we will say more about the doubling effect in Sect. 5).

Nonetheless, before moving ahead, we want to point out an important asymmetry between regular and verb doubling lián...dōu sentences: as attentive readers might have noticed, our examples of verb doubling lián...dōu always contain negation (bù or méi) whereas their regular counterparts don't. More specifically, verb doubling lián...dōu sentences require the presence of either sentential negation or a superlative. As an illustration, consider the following examples.
a. Tā
he
(lián)
$\left[\begin{array}{lll}\text { F } & \text { kàn }\end{array}\right]$ dōu
*(bú)
kàn.
LIAN
'He didn't even look.'
not look
b. (lián) [F chuān] tā dōu yào chuān *(zuì-hăo de). LIAN wear he DOU want wear suP-good DE
'Even when it comes to clothes, he wants to wears the best.'
c. Tā
(lián) [F
chī] dōu chī
eat
*(zuì-guì
de).
he
LIAN
eat
SUP-expensive DE

'He even has to eat the most expensive (thing).'

\footnotetext{
${ }_{17}$ Regardless of whether $d \bar{o} u$ appears in the matrix or embedded clause, a long-distance internal-lián construal is illicit.
} 
Though we do not yet understand why negation or superlative has to appear in verb doubling lián...dōu sentences, we would like to speculate that this may be related to the scalarity requirement exercised upon the verb. Consider first the case of regular lián...dōu sentences, as in (30a), repeated here as (37): the assertion of (37) is that "he finished reading this book", with the existential implicature being that he also finished reading other books. The scalar implicature is that finishing this book is the least likely thing for him to do.

(37) Tā (lián) [F zhè-běn shū] dōu kàn-wán-le.

he LIAN this-CL book DOU read-finish-PERF

'He finished reading even this book.'

Consider now (36b) again in terms of its interpretation. Since lián is attached to the verb, it is the verb that needs to be connected to a scale. It is possible that such a scale can only be established either by polarity (e.g., negation) or by superlatives.

\subsection{Movement effects in lián...dōu sentences}

In Sect. 2.2, we showed that the two verbs in verb doubling clefts belong to an A-bar movement chain that exceptionally allows pronunciation of more than one of its links. The purpose of this subsection is to show that the same holds for verb doubling lián...dōu sentences. In order to justify this claim, we use the same tests as is Sect. 2.2, namely, locality restrictions and lexical identity effects. Below we will only be testing the initial lián sentences (among the verb doubling lián...dōu sentences) since they are the ones which allow long-distance construal.

\subsubsection{Locality constraints}

The claim that regular lián...dōu sentences have a component of focus movement has already been advanced by Shyu (1995) and Badan (2007). As a baseline, consider the following example of a regular lián...dōu sentence, which (similar to (35)) shows that, in principle, finite clause boundaries may intervene between the surface and the thematic position of the focused constituent.

(37) (Lián) [F zhè-běn shū $]_{\mathrm{i}}$ wǒ zhīdào [Ľ̌sì dōu ỵ̌jīng kàn-wán-le $t_{\mathrm{i}}$ ]. LIAN this-CL book I know Lisi DOU already read-finish-PERF

'I know that Lisi has already finished reading even this book.'

However, if an island boundary intervenes, then ungrammaticality results. We illustrate it here with a wh-island.

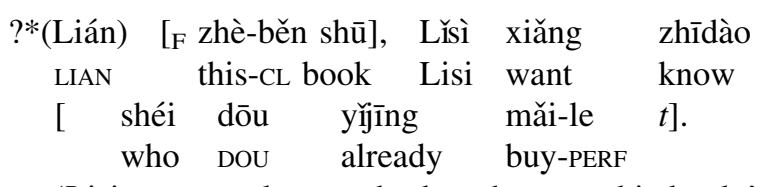

'Lisi wants to know who bought even this book.' 
Additionally, Shyu (1995) and Badan (2007) also note that regular lián...dōu sentences can give rise to both weak and strong crossover effects, further reinforcing the hypothesis that there is movement.

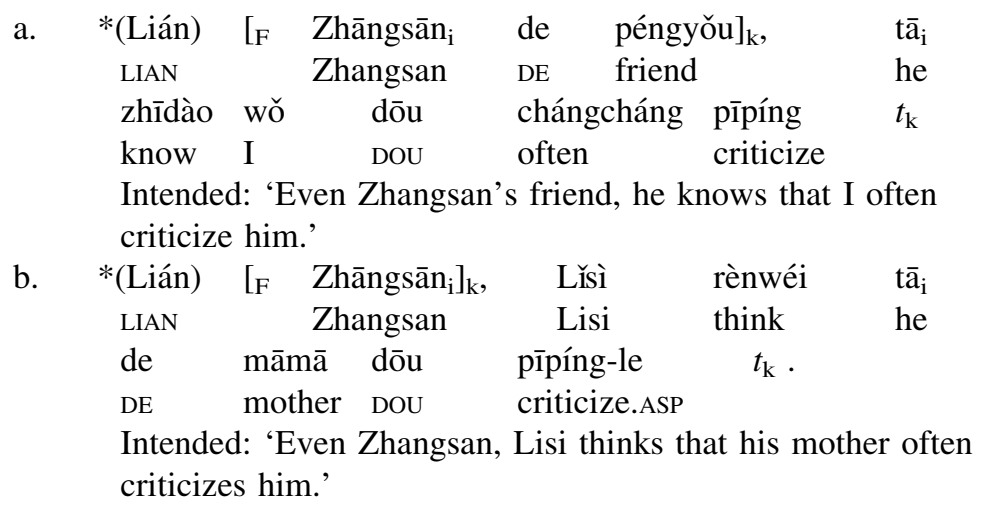

The crossover tests are not applicable to verb doubling lián...dōu sentences, due to the lack of pronominal-predicates that can be co-indexed with the two verbs. However, the locality test is still available to us. As with the regular version of lián...dōu, we begin by considering a baseline example without intervening island boundaries, which shows that, in principle, it is possible for the dependency between the two verbs to span multiple clauses. (35) is repeated here as (40).
(40) (Lián) [F kàn] wǒ xiāngxìn [tā dōu méi kàn]. LIAN look I believe he DOU not.have look
'I believe that he didn't even look.'

However, the dependency is blocked if any of the standard island boundaries intervenes. We illustrate this effect here with a wh-island and an adjunct island. The conclusion is that verb doubling lián...dōu sentences involve an A-bar chain mediating the dependency between the two verbs.

\begin{tabular}{|c|c|c|c|c|c|}
\hline$*$ (Lián) & [F kàn] & wǒ & zhīdào & & \\
\hline LIAN & look & & know & & \\
\hline [tā & wèishěnm & e dōu & méi & kàn]. & \\
\hline he & why & DOU & not.have & look & \\
\hline 'I know y & hy he didn' & 't even & look.' & & \\
\hline *(Lián) & {$[\mathrm{F}$} & kàn] & tā & bèi & chē \\
\hline LIAN & & look & he & by & car \\
\hline zhuàng-le & [yīnwèi & tā & dōu & méi & kàn]. \\
\hline hit-PERF & because & he & DOU & not.have & look \\
\hline
\end{tabular}




\subsubsection{Lexical identity effects}

In Sect. 2.2.2, we saw that verb doubling clefts require the two instances of the verb to be identical and attributed that restriction to the copy theory of movement, on the assumption that the two verbs are two links of the same A-bar movement chain. The same argument can be extended to verb doubling lián...dōu constructions: as the following examples show, it is not possible to use the lower verb to further specify the upper one. ${ }^{18}$

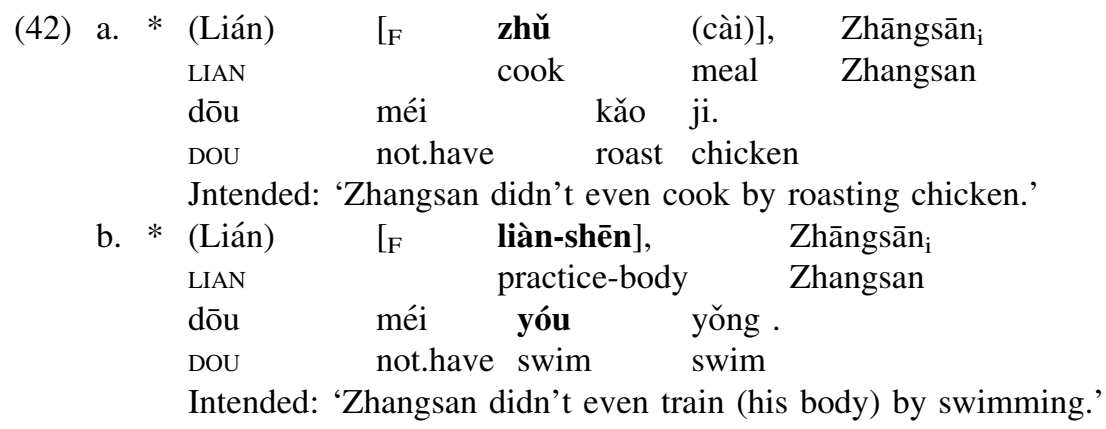

Our explanation is the same as in Sect. 2.2.2: the two instances of the verb in verb doubling lián...dōu sentences are links in one single A-bar chain, which has the property of exceptionally allowing pronunciation of more than one chain link. If so, then the lexical identity effect follows directly from the copy theory of movement. Furthermore, this analysis is consistent with the evidence from locality restrictions discussed in the previous section.

\subsubsection{Potential counter-examples}

We have good evidence that A-bar movement underlies the derivation of both regular and verb doubling lián...dōu constructions. However, Shyu (1995) has argued that a non-movement derivation also seems to be possible, citing as evidence the fact that island effects disappear if $d \bar{o} u$ is placed in the matrix clause. Compare example (38), repeated here as (43), with (44) (dōu is boldfaced in both examples).

18 There are some examples, though, where the two verbs are not identical, which would in principle cast doubt towards this conclusion. We reproduce two of them in (i) below.

(i) a. Lián lüxíng wǒ dōu bú zuò fēijī.

LIAN travel I DOU not sit airplane

'I won't fly even if I (need to) travel.'

b. Lián xiàyǔ wǒ dōu bù dă yǔsăn.

LIAN rain I DOU not hit umbrella

'I won't carry an umbrella even if it's raining.'

Note, however, that these examples have a concessive reading, not the characteristic verum focus reading of verbal lián...dōu. Therefore, we assume that they instantiate a separate construction, and that they don't constitute counter-examples to our claim that verbal lián...dōu is derived via verb movement. 
(43)

$$
\begin{aligned}
& \text { ?*(Lián) [F zhè-běn shū], Lǐsì xiăng zhīdào } \\
& \text { LIAN this-CL book Lisi want know } \\
& \text { [ shéi dōu y̌̉jīng mǎi-le } t \text { ]. } \\
& \text { who DOU already buy-PERF }
\end{aligned}
$$

'Lisi wants to know who bought even this book.'

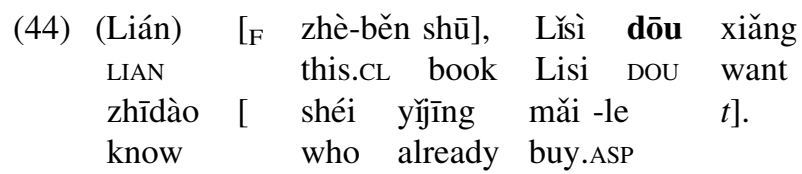

'Lisi wants to know who bought even this book.'

The verb doubling variant behaves differently, though. As the following minimal pair shows, verb doubling lián...dōu sentences only allow placement of $d \bar{o} u$ in the same clause as the lower verb. Compare this with regular lián...dōu where $d \bar{o} u$ can appear in either the matrix or embedded clause; (34a) is repeated as (46a).

(45) a.

$$
\begin{aligned}
& \text { (Lián) [F kàn], wǒ zhīdào Ľsì dōu méi kan. } \\
& \text { LIAN look I know Lisi DOU not look } \\
& \text { 'I know that Lisi didn't even look.' }
\end{aligned}
$$

b. ?* (Lián) [F kàn], wǒ dōu zhīdào Ľsì méi kan. LIAN look I DOU know Lisi not look

'I know that Lisi didn't even look.'

(46) a. (Lián) zhè-běn shū wǒ yřwéi tā dōu kàn-le. LIAN this-CL book I think he DOU read-PERF 'Even this book, I thought that he has read.'

b. (Lián) zhè-běn shū wǒ dōu y̌̌wéi tā kàn-le. LIAN this-CL book I DOU think he read-PERF 'Even this book, I thought that he has read.'

In short, the paradigm can be described as follows: in regular lián...dōu sentences, $d \bar{o} u$ can be placed either in the lower or the upper clause, the latter option voiding the effect of island boundaries. In contrast, verb doubling lián...dōu sentences only allow placement of $d \bar{o} u$ in the lower clause, and therefore there is no possibility of escaping island effects. In order to understand why this asymmetry exists, first we need to understand why a high placement of $d \bar{o} u$ circumvents island violations.

The phenomenon is reminiscent of the paradigm for Japanese wh-questions discussed in Hagstrom (1998). Hagstrom proposes that the sentence-final interrogative particles $k a$ and no are merged in a lower position and reach their surface position via movement. The following example illustrates this type of derivation for a simple question.

$$
\begin{array}{llll}
\text { John-ga } t \text { nani-o } & \text { kaimasita } & \text { ka? } \\
\text { John-NOM } & \text { what-ACC } & \text { bought } & Q \\
\text { 'What did John buy?' } &
\end{array}
$$


The situation is more interesting in questions containing islands. Hagstrom proposes that the emphatic particle ittai 'the hell' necessarily c-commands the trace of Q. If ittai appears inside an island (in this particular case, a relative clause island), then so must the trace of $\mathrm{Q}$, and an island violation ensues due to the extraction of $\mathrm{Q}$ out of the island ((48a)). However, if ittai appears outside the island, then Q itself can also be merged outside the island. In that case, the movement never crosses any island boundaries, and therefore no island violation ensues.

$$
\begin{aligned}
& \text { a. *Mary-wa [ John-ni ittai } t \text { nani-o ageta hito-ni] atta no? } \\
& \text { Mary-top John-DAT ITTAI what-ACC gave man-DAT met Q } \\
& \text { 'Mary met the man who gave what (the hell) to John?' } \\
& \text { b. Mary-wa ittai t } t \text { [John-ni nani-o ageta hito-ni] atta no? } \\
& \text { Mary-Top ITTAI John-DAT what-ACC gave man-DAT met Q } \\
& \text { 'Mary met the man who gave what (the hell) to John?' }
\end{aligned}
$$

We propose that, in the same way as Japanese ittai, Mandarin dōu needs to c-command the trace left by movement of [(lián) Focus] (cf., Huang (1996)). This is illustrated in (49a,b), representing the sentences in (43) and (44), respectively. In (49a), where dōu appears inside the island, (lián) zhè-běn shū 'this book' must also be merged inside the island, with the consequent island violation. In contrast, when $d \bar{o} u$ is placed outside the island, (lián) zhè-běn shū can also be merged outside the island, circumventing what otherwise would be a movement violation ((49b)).

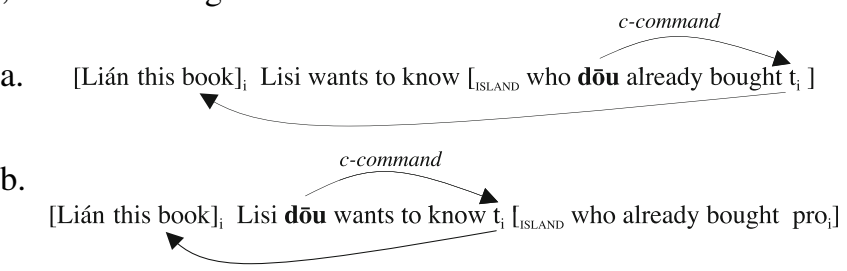

Importantly, note that the latter option creates a theta-role assignment problem: if zhè-běn shü 'this book' is merged in an island-external position, then it cannot receive its theta role in the usual way, as it is too far away from the verb. The obvious way to solve this problem is by inserting a silent pronoun in the thematic position and then linking it to the island-external zhè-bèn shū 'this book' by predication. This process only requires lambda abstraction to turn the island into a predicate, with zhè-b̌rn shū 'this book' merged as the subject of predication. ${ }^{19}$ This

\footnotetext{
19 A sketch of this process goes as follows (interested readers are referred to Hagstrom (1998), Cable (2004), Rezac (2004), or Büring (2005), where a much lengthier discussion is available). The effect of lambda abstraction is to turn a proposition (in this case, the island constituent) into a predicate that requires saturation. If the lambda element bears the same index as a constituent $x$ inside the predicate, then the constituent to be merged next (the subject of predication) will have the same index as $x$, i.e., the subject of predication will bind $x$ without any movement operation having taken place. As the authors above show at length, this process underlies a number of island-insensitive dependencies across languages, including some (e.g., Japanese ittai) that are very similar to Shyu's lián...dōu paradigm.
} 
much in place, the asymmetry between regular and verb doubling lián...dōu sentences reduces to the fact that, while Mandarin has null pronouns that can receive the appropriate theta-role, it lacks (by hypothesis) null pro-verbs that can assign the relevant theta-roles. ${ }^{20}$ In other words, in verb-doubling lián...dōu sentences, the verb must always be merged in a low position so that it can establish the correct thematic relations between its arguments. If this position happens to be located inside an island, then movement to an island-external position will invariably result in ungrammaticality.

In sum, the analysis we have developed in this section suggests that, in all verb doubling lián...dōu sentences, the two instances of the verb are links of the same movement chain. In regular non-verbal lián...dōu sentences, the [(lián) Focus] can be merged outside the island, thus circumventing locality restrictions. However, this possibility is not available for verb doubling lián...dôu sentences, due to theta-role assignment factors. Consequently, we are justified in our earlier claim that verb doubling lián...dōu sentences always have an A-bar movement chain mediating the dependency between the two verbs.

\subsection{Interim conclusion II}

In this section we have seen that regular and verb doubling lián...dōu pattern together in a number of aspects, e.g., optionality of lián, placement of the focused constituent, different position of [(lián) FOCus] with respect to the subject, and sensitivity to islands. We argue that both classes of sentences share a common syntax. As in the case of clefts in the Sect. 2, the verb doubling effect seems to be epiphenomenal.

\section{Verb doubling clefts and lián...dōu sentences as a probe into the nature of verb movement}

\subsection{Preliminaries}

So far, we have shown that, in both verb doubling clefts and verb doubling lián...dōu sentences, the relation between the two verbs is one of movement. We have done so by showing that prototypical movement effects hold between the two verbs. More specifically, we have proposed that the verbs are members of one and the same movement chain that has the exceptional property of allowing spell-out of more than one chain link.

In this section, we turn to the nature of that movement. Given that the movements in question show prototypical A-bar properties, one might assume that we are dealing with a case of remnant predicate movement, as attested in Russian, amongst other languages. Consider, for instance the following Russian example (Abels 2001).

\footnotetext{
${ }^{20}$ Note that Cheng (2008) posits a pro-predicate in bare shì sentences, on a par with it in sentences like it is $m e$ in English. Such pro-predicates do not assign theta-roles.
} 
(50) Russian

Citat, Ivan ee citaet.

read.INF Ivan it reads

'As for reading, Ivan does read it.'

Abels shows that the infinitive citat and the finite verb citaet stand in a movement relation analogous to the one we have proposed for Mandarin verb doubling clefts and verb doubling lián...dōu sentences. In terms of implementation, he argues in favor of remnant VP movement: all VP-internal sub-constituents are evacuated to a VP-external position, and then a VP containing the verb as its only overtly realized constituent is moved to the left edge of the sentence (here we are glossing over the finite-verb-to-infinitive conversion, which is a morphological effect due to the fact that the fronted VP is not large enough to contain tense/agreement-related functional structure; see Abels (2001) and references therein for discussion). (51) illustrates such movement.

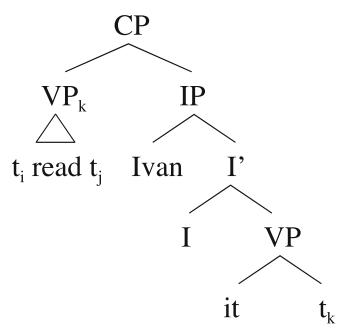

Importantly, though, Abels points out that this analysis is feasible because Russian has a very productive scrambling process (cf. Bailyn 1995), which can be invoked on all necessary occasions. This is in line with den Besten and Webelhuth's (1987) conjecture that partial predicate fronting is possible only in those languages that have a sufficiently productive rule of scrambling, e.g., German but not English.

These precedents offer us a baseline to evaluate the merits (or lack thereof) of a remnant movement analysis for the Mandarin data. Specifically, if we wish to analyze verb doubling clefts and verb doubling lián...dōu sentences in terms of remnant VP movement, we would expect Mandarin to exhibit German- or Russianstyle scrambling. This seems a reasonable requirement to us. If this were not the case, that is, if there are VP-internal constituents that can be stranded but cannot be affected by scrambling, then a remnant predicate movement analysis would require postulating ad hoc movements for the sole purpose of creating a remnant predicate.

It is true that Mandarin has some amount of scrambling (Soh 1998), but we show below that it is not productive enough. Demonstrably, the domain of application of Mandarin scrambling is too limited to routinely evacuate the (extended) VP of all non-verbal constituents that can be stranded under verb movement in verb doubling 
clefts and verb doubling lián...dōu. Consequently, we conclude that remnant movement cannot underlie these constructions. ${ }^{21}$

\subsection{Scrambling in Mandarin}

Soh (1998) discusses alternations like the following, where an object can appear on either side of a duration/frequency phrase (cf. also Tang 1994; Sybesma 1997).
a. Wǒ qǐng-guò [nà-ge rén] [liăng cì].
I invite-EXP that-CL person two time
'I invited that person twice.'
b. Wǒ qǔng-guò [liăng cì] [ nà-ge rén].
I invite-EXP two time that-CL person
'I invited that person twice.'

Soh proposes that (52b) is the base order and (52a) is derived via movement (scrambling) of the object across the adverb. She justifies this analysis on the basis of the scope possibilities observed in each order; in particular, the [adverb-object] order only allows direct scope $((52 \mathrm{c}))$, whereas the [object-adverb] order allows both direct and inverse scope (52d). ${ }^{22}$ Soh's proposal is that inverse scope in (52d) arises through reconstruction of the quantified object to its base position below the adverb.

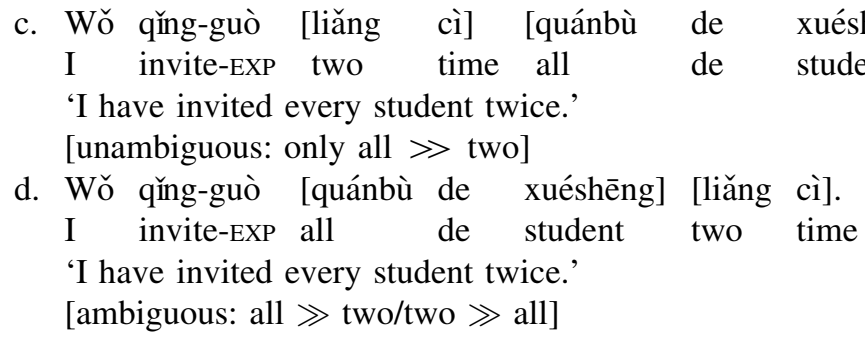

\footnotetext{
${ }^{21}$ A reviewer notes an example such as (i), with an adverbial modifying the verb and still yielding doubling, as an example that is not predicted by our analysis.
}

(i) \#lián [guānshàng mén xiǎoshēng-de shuō] tā dōu bú yuàn shuō LIAN close door low.voice-de talk he dou not willing talk

Intended: 'He is not willing to talk even with the door closed and with a low voice.'

However, we have checked this sentence with several native Mandarin speakers. Some completely ruled this sentence out, and some considered it to be marginal.

22 This is the same paradigm as in languages where object scrambling is commonly accepted. Consider, as an illustration, the following Dutch examples.

$\begin{array}{llllllll}\text { (i) Ik heb met twee } & \text { appelen vier appeltarten gebakken. } & \\ \text { I } & \text { have } & \text { with two } & \text { apples } & \text { four apple-pies baked } & {[2>4 / * 4>2]} \\ \text { (ii) Ik heb vier appeltarten } & \text { met } & \text { twee appelen gebakken. } & \\ & \text { I have four apple-pies } & \text { with } & \text { two apples } & \text { baked } & {[2>4 / 4>2]}\end{array}$

Example (i), with an [adverb-object] order, represents the base order and therefore allows only direct scope; example (ii) is the scrambled order and therefore allows both direct and inverse scope (the latter, under reconstruction of the object to its base position below the adverb). See Lechner (1998) for discussions on scope reconstruction as a result of scrambling. 
Given these data, we agree with Soh that Mandarin has scrambling. However, typically, objects do not scramble to the left of the verb though it is possible to raise the object to the left of the verb and below the subject. Badan (2007) argues that bare noun phrases (without lián) in the position between the subject and the verb are contrastive topics, as in (53).

Zhāngsān nà-běn shū hái méi $\quad$ kàn-wán
Zhangsan that-cL book still not.have read-finish
'Zhangsan has not finished reading that book (but has finished some
other book(s)).'

To implement a remnant movement analysis for verbal doubling clefts and verb doubling lián...dōu sentences, everything that is inside the verb phrase has to first exit the verb phrase; moreover, the second copy of the verb also has to subsequently raise to a post-subject position to ensure the right order, as indicated in (54b) for a sentence such as (54a).

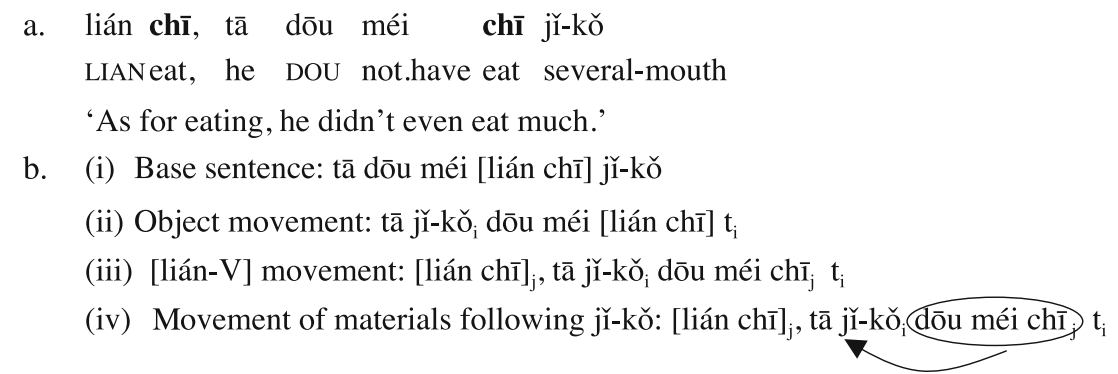

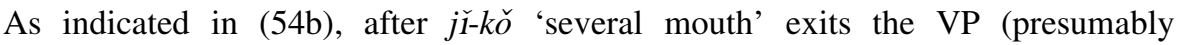
undergoing movement of contrast topics), lián chī can in principle undergo remnant VP movement. However, as we can see from step (54b-iii), after the lián chi movement, the word order is not correct. To get the right word order, not only is it the case that what precedes the verb (in this case $d \bar{o} u$ and méi) needs to move to precede $j \check{1}$-kŏ, the verb copy also needs to undergo further movement.

However, in neither verb doubling clefts nor verb doubling lián...dōu is it the case that the post-verbal material must be interpreted as topics. Further, it is unclear what drives the movement of all these constituents, let alone the verb copy itself. We therefore conclude that the remnant movement analysis is not feasible for these two types of sentences.

\subsection{An alternative to remnant movement}

The situation we have just described is not exclusive to Mandarin. Lema and Rivero (1989) famously pointed out that infinitive fronting in the Slavic languages cannot be remnant VP movement due to the fact that these languages appear to lack VP movement altogether. Later research has uncovered similar situations in a variety of 
languages. For instance, Holmberg (1999) observes that finite verbs in Icelandic can move to the left periphery through the process known as Stylistic Fronting. Crucially, this movement cannot be remnant movement because Holmberg's Generalization prevents Icelandic objects from moving to a structurally high enough position to create a remnant constituent. Fanselow (2002) makes a similar argument for German, observing that certain constituents that strongly resist scrambling (e.g., negative indefinites, resultative predicates, and verbal particles) can nonetheless be stranded under partial predicate fronting; therefore, at least some instances of this construction must be derivable without resort to remnant movement. Finally, Landau (2006) and Vicente (2007) reach the same conclusion for the predicate cleft constructions in Hebrew and Spanish, respectively, for exactly the same reason: scrambling in these languages is demonstrably not powerful enough to create a remnant constituent in every case it would be required.

If we wished to analyze the constructions in the previous paragraph (as well as the relevant Chinese examples in the previous sections) as cases of remnant VP movement, then we would have to say that the languages in question have a process which can evacuate VP-internal constituents as required to create a remnant VP but which is otherwise undetectable. Various researchers (e.g., Koopman and Szabolcsi (2000); Hinterhölzl (2002); Mahajan (2003)) have argued in favor of this possibility on the assumption that the evacuating movements are not "scrambling" or "object shift" as traditionally understood but are rather required for the licensing of verbal dependents. Nonetheless, we choose to reject this possibility for the same reasons that Landau (2006) does:

Perhaps one could argue that the movement vacating VP need not be scrambling, for example, it could be movement for licensing purposes (Hinterhölzl 2002). The problem is that such movement is never attested without VP fronting [...], and furthermore, there seems to be no restriction whatsoever on the type of elements that can be stranded under VP fronting (PPs, secondary predicates, etc.). [...] Relabeling "scrambling" as "licensing movement" does not advance our understanding of the construction. (Landau (2006:51), our emphasis)

If the fronting does not involve remnant VP movement, what are our analytical options for verb doubling clefts and verb doubling lián...dōu? All the works cited above converge on the conclusion that, on top of standard head-to-head movement, bare heads must be allowed to move long distance, in a manner that resembles regular A-bar movement. This is essentially the same proposal one finds in Koopman (1984), who proposed that the A vs. A-bar movement distinction has a correlate in the realm of head movement. We adopt this idea but not Koopman's terminology. The reason is that, as an anonymous reviewer points out, the A vs. A-bar movement asymmetry is based on a property of XPs that doesn't have any obvious correlate in the realm of heads. Thus, we will distinguish between local head movement and long-distance head movement. Local head movement (what Koopman calls A head movement) is regular head-to-head movement, as originally defined in Travis (1984) and Baker (1985), and it is arguably driven by selectional and/or morphological factors (cf. Svenonius (1994); Matushansky (2006); Vicente 
(2007)). Long-distance head movement (Koopman's A-bar head movement), on the other hand, is the mechanism proposed by the researchers cited above, that is, a mechanism that moves a bare (verbal) head, to the exclusion of its dependents, to a focus/topic position in the left periphery, potentially across finite clause boundaries, and which shows sensitivity to island boundaries. More specifically, we adopt the details of implementation in Toyoshima (2001), Matushansky (2006), Vicente (2007), and Roberts (2010), who propose that long-distance head movement proceeds in the same way as A-bar phrasal movement, i.e., it moves a constituent (in this case, a head) to a specifier position in the left periphery (or, alternatively, in a phasal edge), for the purpose of satisfying some feature typically associated with this region of clausal structure, e.g., topic, focus, etc.

We appreciate that the existence of long-distance head movement might at first sight seem an unmotivated stipulation. We, however, follow Toyoshima, Matushansky, Vicente, and Roberts in their claims that the opposite is actually the case: within the current syntactic framework (especially given the Bare Phrase Structure hypothesis), the existence of this kind of head movement is expected, and trying to rule it out would require a number of stipulations. The requirement that head movement should not skip heads (the Head Movement Condition) was originally implemented as a corollary of the ECP, on the assumption that the skipped head would block the moved head from properly governing its trace. However, the abandonment of the notion of proper government rendered this analysis meaningless. More recent work (Svenonius (1994); Pesetsky and Torrego (2001)) has advanced the alternative hypothesis that "traditional" head movement is the overt expression of subcategorization (c-selection). Every head comes with a subcategorization requirement that must be satisfied by its complement (assuming that this requirement is encoded as a formal feature, called a $c$-feature Svenonius (1994)). If the subcategorizing $c$-feature overtly attracts the subcategorized category, the result is classical head-to-head movement. Therefore, it follows that head-to-head movement is very local because subcategorization itself is very local.

It hasn't escaped the attention of many researchers (cf. the works cited above) that this implementation opens an interesting loophole. Suppose that the attracting feature is not a subcategorizing $c$-feature but rather a discourse-related feature like [topic] or [focus] residing in a left-peripheral projection. If so, nothing blocks long distance movement of a topic- or focus-marked bare head, and the result is that one predicts that bare heads ought to be able to exhibit A-bar movement characteristics. As we made clear at the beginning of this section, this situation is widely attested typologically. Our proposal is that such movement is also attested in Mandarin verb doubling clefts and verb doubling lián...dōu, a claim which has not yet been made.

Under this hypothesis, the relevant verb in verb doubling clefts undergoes movement from $v$ to a topic position in a Rizzian left periphery (Rizzi (1997)) through the edge of the SC subject ((55a)). Similarly, in a verb doubling lián...dōu sentence, the verb moves from $\mathrm{v}$ to a contrastive topic position associated with the focus marker lián ((55b)). Specifically, we take lián to be the head of this projection, with $v$ undergoing A-bar movement to the specifier of this projection (with subsequent morpho-phonological merger of lian and the verb; see Matushansky (2006)). As we explained in the previous subsection, this movement cannot be 
remnant predicate $(\nu \mathrm{P})$ movement, given that Mandarin lacks the capability to produce a remnant $v \mathrm{P}$ in all the cases where it would be required.

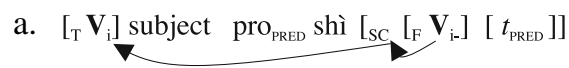

b. [V] lián subject dōu NEG V

\section{The doubling effect}

So far, we have taken the doubling effect in verb doubling clefts and verb doubling lián...dōu sentences as a given, without attempting to analyze its ultimate cause. A complete analysis of verb doubling clefts and verb doubling lián...dōu sentences should contain a proper explanation of this effect. In what follows, we offer a brief discussion of its possible causes.

As a first step, let us consider the two different causes of this kind of doubling effect proposed in the literature.

- Doubling is a morphological repair mechanism (van Riemsdijk (1989); Abels (2001); Landau (2006)): movement separates a lexical root from some bound morphemes. Given that bound morphemes require a host, pronunciation of a low copy of the root is exceptionally permitted so as to avoid a morphologically deviant structure.

- Doubling is a consequence of morphological fusion (Nunes (2004); Corver and Nunes (2007)): under certain circumstances, one of the links of a movement chain may morphologically fuse with an adjacent constituent, forming a complex head. The internal structure of the resulting head is, by hypothesis, invisible for the linearization algorithm, and therefore it cannot be targeted by the chain reduction process.

In what follows, we consider each possibility for both verb doubling clefts and verb doubling lián...dōu sentences. We argue that morphological fusion cannot be the cause of doubling even though morphological fusion appears to have more promise. We discuss the core problem facing the morphological fusion analysis in Sect. 5.3.

\subsection{Doubling as morphological repair}

As mentioned above, the main idea behind the morphological repair hypothesis is that double pronunciation is a strategy to salvage a structure that would otherwise be morpho-phonologically deviant. The classical example of this effect is the following German paradigm (van Riemsdijk 1989): the negative quantifier kein 'no' is a portmanteau of the existential quantifier ein plus sentential negation.

(56) Sie kennt keinen alten Professor.

she knows no old professor

[where keinen $=\neg+\exists$ ] 
Importantly, negation and the existential quantifier are syntactically independent from each other, as evidenced by the fact that the existential quantifier can undergo Quantifier Raising independently of negation (see von Stechow (1993)). However, overt movement of the existential quantifier stranding negation is not possible, given that negation is expressed through the bound morpheme $k$-, which (by definition) cannot stand on its own.

$$
\begin{array}{clllll}
* & \text {-einen } & \text { alten } & \text { Professor } & \text { kennt } & \text { sie } \\
\text { a } & \text { old } & \text { professor } & \text { knows } & \text { she no }
\end{array}
$$

Nonetheless, this structure can be salvaged if einen is spelled out in its leftperipheral landing site as well as in its original position next to negation. With double spell-out, the morpho-phonological problem caused by a free-standing $k$ - is solved.

(58) Einen alten Professor kennt sie keinen.

a old professor knows she none

Some languages exhibit the same effect in the verbal domain. For instance, Hungarian cannot front a verbal root (realized as an infinitive) while stranding tense and agreement morphology. The problem is the same as above, i.e., that tense and agreement morphology are bound morphemes and therefore stranding them causes the same deviance as stranding of $k$ - in (58) above. This problem can be solved similarly by spelling out the verb root in both positions (data from Vicente (2007)).

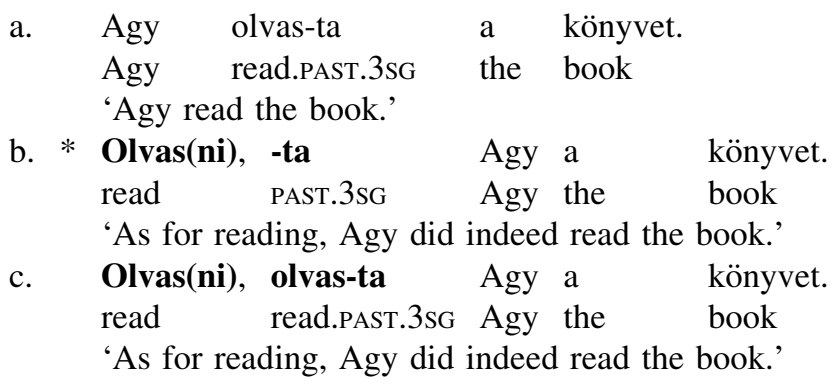

The pertinent question is whether this reasoning is applicable to verb doubling clefts and verb doubling lián...dōu. Our answer is that it is not: unlike the languages for which morphological repair has been proposed as the cause of doubling, Mandarin verbs carry no bound tense or agreement morphemes that can be stranded. Therefore, no morpho-phonological deviance can arise. ${ }^{23}$ An anonymous reviewer suggests that treating aspectual morphemes as bound morphemes could produce the result we are seeking. However, this cannot be the driving force of verb doubling either, as the presence of aspectual markers is not required for doubling, as shown in (60) (examples repeated from (9c) and (36c)).

\footnotetext{
${ }^{23}$ Mandarin might still have a silent representation of tense, qua a T head without an exponent. However, this is irrelevant: by definition, stranding a null morpheme cannot give rise to the kind of morphophonological deviance that would trigger doubling.
} 
(60) a. Chī, wǒ shì tiāntiān chī, ..

eat, I COP daily eat

'As for eating, I certainly eat every day, but...'

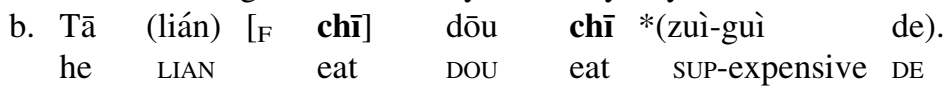

'He even has to eat the most expensive (thing).'

In short, we conclude that the doubling effect in verb doubling clefts and verb doubling lián...dōu cannot be attributed to a morphological repair process.

\subsection{Morphological fusion}

The second strategy underlying double pronunciation of chain links is based on the notion of morphological fusion (Marantz (1984); Embick and Noyer (2001); Nunes (2004); Matushansky (2006)), whereby two independent but linearly adjacent syntactic terminals are combined into one.

(61) Morphological fusion of $\alpha$ and $\beta$ (linear order irrelevant) $[\alpha][\beta] \rightarrow[\alpha \beta]$

Nunes (2004) assumes that morphological fusion renders the internal structure of the $[\alpha \beta]$ constituent invisible for syntactic purposes. This assumption has important consequences whenever either $\alpha$ or $\beta$ is a link in a movement chain, as in the following representation.

(62) Morphological fusion of $\alpha$ and $\beta$ (linear order irrelevant) $[\alpha][\beta] \ldots[\beta] \rightarrow[\alpha \beta] \ldots[\beta]$

Specifically, the requirement that only one link of a movement chain is pronounced is not applicable to this case because the upper copy of $\beta$, having been fused to $\alpha$, is by hypothesis no longer visible to the linearization algorithm. In other words, from the perspective of the linearization algorithm, there is only one syntactically relevant instance of $\beta$, namely, the lower one. The upper one is contained inside the fused constituent $[\alpha \beta]$ and is therefore inaccessible for the linearization algorithm. As a consequence, the chain reduction process is bled, and both instances of $\beta$ are pronounced.

This particular strategy might seem more plausible a priori, given that Cheng (2007) has already suggested that it is at work in an unrelated case of verb doubling in Mandarin, viz, resultative predicates, where the lower copy of the verb fuses with the resultative head $d e$, as exemplified in (63). ${ }^{24}$

(63) Tà qú nèi-p̄i mǎ qí de hěn lèi. 'He rode that horse, and the horse got tired as a result of riding.'

\footnotetext{
${ }^{24}$ It should be noted that Cheng (2007) proposes two sources for verb copying. One is discussed in the text, and the other one is derived through sideward movement, which will not generate a c-command relation between the $\mathrm{O}$ in the VO complex and the rest of the sentence. See Cheng (2007) for details.
} 
Given this precedent, we may reasonably ask whether the same process underlies doubling in verb doubling clefts and verb doubling lián...dōu. We will consider both constructions in turn, beginning with the latter.

\subsubsection{Morphological fusion in verb doubling lián...dōu?}

In the verb doubling lián...dōu construction, we have three invariant elements that are potential hosts for morphological fusion, namely, (i) lián; (ii) $d \bar{o} u$; and (iii) the required negation or superlative element. It is quite easy to show that neither $d \bar{o} u$ nor negation or the superlative can morphologically fuse with the verb. As explained above, morphological fusion requires linear adjacency of the constituents involved; however, there is no requirement that $d \bar{o} u$, negation, or the superlative be adjacent to the verb, even in cases where doubling obtains; see the examples below. Therefore, this particular analysis could perhaps be invoked on selected cases but definitely not on a general basis.

$$
\begin{aligned}
& \text { a. Lián kàn tā dōu bù xiăng kàn } \\
& \text { lian see he dou not want see } \\
& \text { 'He didn't want to even look.' } \\
& \text { b. Lián kàn tā dōu bù yídìng kàn } \\
& \text { lian see he dou not certainly see } \\
& \text { 'He doesn't necessarily even look.' } \\
& \text { c. Tā (lián) [ [ } \mathrm{F}_{\mathrm{F}} \text { chī] dōu chī-guò *(zuì-guì de). } \\
& \text { he LIAN eat DOU eat-EXP suP-expensive DE } \\
& \text { 'He has even eaten the most expensive (thing).' }
\end{aligned}
$$

The remaining option is that the verb fuses with lián, given that lián (unlike $d \bar{o} u$, negation, or the superlative) is necessarily adjacent to the upper copy of the verb. However, recall that the presence of lián is optional. As we showed in example (31b), repeated here as (65), verb doubling obtains even when lián is not overtly realized.

(65) (Lián) [F kàn], tā dōu méi làn.
LIAN look he DOU not.have look
'He didn't even look.'

Badan (2007) argues that lián (i.e., the contrastive focus head it is associated with) is always present in syntax although it may not be spelled out in phonology. ${ }^{25}$ This means that lián can qualify as a host for morphological fusion only to the extent that we want to allow morphological fusion to involve null elements. Nunes and Quadros (2006) argue that this is a licit operation, on the grounds that focus-related doubling in Brazilian Sign Language (BSL) obtains without any apparent overt head

\footnotetext{
25 Badan (2007) shows that in a sentence with $d \bar{o} u$ and without lián, to achieve the same reading as we have with lián, the noun phrase preceding $d \bar{o} u$ needs to have a special phonological prominence. She concludes that in such a case, even though lián is not spelled out, the head with which it is associated is still present.
} 
that the focus can fuse with. Consider one of their examples (BSL realizes focus on the right edge of the sentence).

\section{(66) I LOSE BOOK [F LOSE]}

'I did lose the book.'

Nunes and Quadros' proposal is that the upper copy of LOSE fuses with a phonetically null focus head, thus feeding double pronunciation. If we extend this analysis to Mandarin, then we could say that the upper copy of the verb always fuses with lián, irrespective of whether lián is phonetically realized or not.

\subsubsection{Morphological fusion in verb doubling clefts?}

Let us turn now to verb doubling clefts. For convenience, we repeat an example of this construction here:

(67) Chī, wō shì chī-guò, búguò...

eat I COP eat-EXP but

'As for eating, I did eat (but...)'

Verb doubling clefts provide two potential candidates to trigger fusion. One of the candidates is the aspectual (experiential) marker, i.e., guò in the previous example. This possibility we will dismiss for the same reason as in the previous subsection, namely, verb doubling occurs even in sentences without an aspectual marker. Some examples follow to illustrate this property.

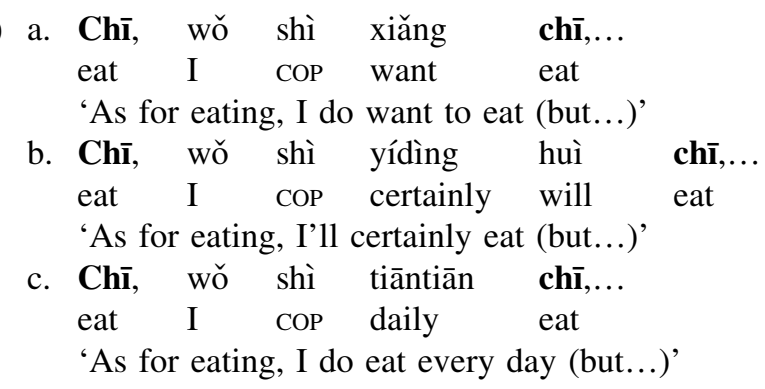

The other candidate to host morphological fusion is the copular verb shì. This one we must also discard. As the previous set of examples shows, there is no requirement that shi be linearly adjacent to any of the copies of the doubled verb. Given that linear adjacency is a necessary requirement for morphological fusion to occur, we can conclude that the verb is not undergoing fusion with shi either.

Having eliminated both aspectual markers and the copular verb as possible hosts for fusion, we still need to contend with the possibility that we raised at the end of the previous subsection, namely, that the verb undergoes fusion with a phonetically null head, in this case, a focus head. If, as Nunes and Quadros (2006) have proposed, a null head can indeed play a role in morphological fusion, doubling in verb doubling clefts can be attributed to morphological fusion. 


\subsection{Problem and interim conclusions}

We have seen in the previous sections that the doubling effect in Mandarin verb doubling clefts and verb doubling lián...dōu cannot be subsumed under morphological repair because Mandarin lacks the kind of bound morphemes that this particular strategy requires. An analysis in terms of morphological fusion succeeds only to the extent that we grant that morphological fusion can take place with a phonetically null functional head. This assumption is reasonably well motivated, given the existence in other languages of doubling effects involving null functional heads (e.g., focus-induced doubling in BSL).

However, morphological fusion is not without problems: in both the lián...dōu and the cleft constructions, only verbs (or predicates) may be doubled. ${ }^{26}$ (69a,b) shows that doubling of a nominal constituent (even if it is a pronoun) results in ungrammaticality in the lián...dōu and the cleft constructions, respectively.
a. *
Lián tā dōu tā
kàn-le
zhè-běn shū.
lian he dou he
read-PERF
this-CL book
'Even he has read this book.'
b. shū, wǒ shì kàn-le (*shū), ...
book I COP read-PERF book
'Books, I have read, ...'

On the other hand, BSL does not suffer from this restriction and can double nominal and verbal constituents alike, as in (70), from Nunes and Quadros (2006).

\section{(70) JOHN SEE WHO YESTERDAY [F WHO] \\ 'Who exactly is it that John saw yesterday?'}

If we assume that the BSL paradigm is the default one, then regardless of the categorial status of the head, fusion should take place. It suggests then that morphological fusion also cannot be the cause of doubling in verb doubling lian...dou and verb doubling clefts. If the BSL paradigm is not the default one, the restriction on fusion with nominals needs to be understood since such an asymmetry does not follow directly from a pure morphological fusion analysis. ${ }^{27}$

Given that the main focus in this paper does not lie on the causes of the doubling effect, our discussion above notes the difficulties raised by trying to subsume the doubling effect under any of the existing mechanisms. Future research is needed to further shed light on the nature of doubling in these two constructions.

\footnotetext{
${ }^{26}$ As mentioned in footnote 1, data provided in Liu (2004) also show doubling in non-verbal predicates (e.g., nominal predicates).

27 In previous incarnations of this work, we had proposed that the asymmetry in Mandarin was related to the phrasal status of the doubled constituents. By hypothesis, morphological fusion accepts only heads as inputs (Nunes (2004) and references cited therein). DPs would be unable to undergo fusion, given that they are phrasal (including pronouns, cf. Déchaine and Wiltschko (2002) and references therein), and therefore their movement chains would be subject to chain reduction as usual. On the other hand, verbs are heads, and therefore fusion is possible. However, the BSL data argue against this analysis, given that bare $w h$-words arguably have a complex internal structure comparable to that of pronouns (Cable (2007) and references), yet this does not prevent fusion.
} 


\section{Conclusions and outlook}

We have achieved two major empirical results in this paper. First, we have shown that verb doubling clefts and verb doubling lián...dōu sentences have the same internal syntax as their non-verbal counterparts, in the sense that they all involve movement of the relevant constituent to a designated focus/topic position. Second, we have shown that, in the case of the verbal versions, movement of a bare verb without its dependents cannot be modeled as remnant VP movement as Mandarin lacks the means (scrambling/object shift) to create a remnant VP in every case where it would be necessary.

More interesting than the empirical results themselves, though, is the fact that each of them comes with a theoretical consequence that supports certain recent lines of research in syntax. Consider first the fact that the verbal and non-verbal versions of clefts and lián...do u sentences have an identical syntax. This parallelism suggests very strongly that the doubling effect observed in the verbal versions is epiphenomenal, i.e., it is caused by factors independent of the syntax of clefts and lián...dōu sentences, and therefore it ought to be characterized as an extrasyntactic effect. In saying this, we converge with Abels (2001), Nunes (2004), Landau (2006), Kandybowicz (2006), Vicente (2007), and a number of other researchers who have examined comparable constructions in other languages, all of whom conclude that the cause of the doubling effect is to be located strictly at PF. More precisely, they all agree that the doubling effect is caused by a perversion of the Chain Reduction process, which under normal circumstances would allow only one link of a movement chain to be spelled out.

Second, the fact that verb doubling clefts and lián...dōu sentences resist a remnant movement analysis has implications for the formal theory of movement. In particular, if a bare verbal head undergoes what can only be characterized as longdistance A-bar movement and if it is not possible to model this movement as remnant VP movement, then it must be the case that, just as it appears at first sight, the bare verbal head in question is undergoing long-distance A-bar movement. This conflicts with the standard theory of movement that grew out of the GB tradition, where movement of heads is necessarily very local. Nonetheless, a number of researchers in the last decade (Toyoshima (2001); Matushansky (2006); Vicente (2007), (2009)) have independently argued in favor of modifying the existing theory of movement so that bare heads are able to undergo the same kinds of movement as phrases, including long-distance A-bar movement, exactly what we have argued in this paper.

While these are important results, we are nonetheless aware that we have left a number of questions open. Most prominently, we have not provided a principled explanation as to why the doubling effect affects only verbal constituents. In fact, we have shown that the standard explanations for a doubling effect in other languages (morphological repair and morphological fusion) fail to extend to Mandarin. We are hopeful, though, that future work will supply some insights into this and other issues. 
Acknowledgments Different versions of this paper has been previously presented at various venues. For their comments and suggestions, we want to thank the audience at the Symposium of Chinese syntax and semantics in City University of Hong Kong, the Linguistics Colloquium series at the University of California, Santa Cruz, IACL 17, and Summer School in Linguistics at Beijing University for comments and discussions. We would also like to thank Yiya Chen, Chin-hui Lin, Dylan Tsai, Luther Liu, and Jo-Wang Lin for their help with native speaker judgments.

Open Access This article is distributed under the terms of the Creative Commons Attribution License which permits any use, distribution, and reproduction in any medium, provided the original author(s) and the source are credited.

\section{References}

Abels, Klaus. 2001. The predicate cleft construction in Russian. In Proceedings of FASL 9, ed. S. Franks et al., 1-18. Ann Arbor: Michigan Slavic Publications.

Badan, Linda. 2007. High and low periphery: A comparison of Italian and Chinese. Ph.D. dissertation, Università degli Studi di Padova.

Badan, Linda. 2008. The even-construction in Mandarin Chinese. In Chinese linguistics in Leipzig, ed. R. Djamouri, and R. Sybesma, 101-116. Paris: EHESS-CRLAO.

Bailyn, John. 1995. A configurational approach to Russian free word order. Ph.D. dissertation, Cornell University.

Baker, Mark. 1985. Incorporation: A theory of grammatical function changing. Ph.D. dissertation, MIT.

Bastos, Ana. 2001. Fazer, eu faço! Topicalização de constituents verbais em portugues brasileiro [As for doing, I do! Topicalization of verbal constituents in Brazilian Portuguese]. M.A. thesis, Universidad Estadual de Campinas.

Büring, Daniel. 1997. The meaning of topic and focus: The 59th Street bridge accent. London: Routledge. Büring, Daniel. 2005. Binding theory. Cambridge: Cambridge University Press.

Butler, Jonny. 2003. Phase structure, phrase structure, and quantification. Ph.D. dissertation, University of York.

Cable, Seth. 2004. The Yiddish predicate cleft construction: A base-generation analysis. Ms., MIT.

Cable, Seth. 2007. The grammar of Q. Ph.D. dissertation, MIT.

Cheng, Lisa L.-S. 2007. Verb copying in Mandarin Chinese. In The copy theory of movement on the PF side, ed. N. Corver, and J. Nunes, 151-174. Amsterdam: John Benjamins.

Cheng, Lisa L.-S. 2008. Deconstructing the shi...de construction. The Linguistic Review 25: 235-266.

Cheng, Lisa L.-S. 2009. On every type of quantificational expression in Chinese. In Quantification, definiteness, and nominalization, ed. M. Rather, and A. Giannakidou, 53-75. Oxford: Oxford University Press.

Constant, Noah, and Chloe Chenjie Gu. 2008. Mandarin even, all, and the trigger of focus movement. In UPenn working papers in linguistics, vol. 14, ed. J.S. Stevens, 1-10. Philadelphia: University of Pennsylvania.

Corver, Norbert, and Jairo Nunes. 2007. The copy theory of movement. Amsterdam: John Benjamins.

Déchaine, Rose-Marie, and Martina Wiltschko. 2002. Decomposing pronouns. Linguistic Inquiry 33: 409-422.

den Besten, Hans, and Gert Webelhuth. 1987. Remnant topicalization and VP structure in the Germanic OV languages. GLOW Newsletter 18: 15-16.

den Dikken, Marcel. 2006. Relators and linkers, the syntax of predication, predicate inversion and copulas. Cambridge: MIT Press.

Drubig, H. Bernhard. 1994. Island constraints and the syntactic nature of focus and association with focus. Arbeitsbericht Nr. 51 des Sonderforschungsbereichs 340. Tübingen: University of Tübingen.

Embick, David, and Rolf Noyer. 2001. Movement operations after syntax. Linguistic Inquiry 32: $555-595$.

Fanselow, Gisbert. 2002. Against remnant VP movement. In Dimensions of movement, ed. A. Alexiadou, et al., 91-127. Amsterdam: John Benjamins. 
Frascarelli, Mara, and Roland Hinterhölzl. 2007. Types of topics in German and Italian. In On information structure, meaning, and form, ed. S. Winkler, and K. Schwabe, 87-116. Amsterdam: John Benjamins.

Gao, Qian. 1994. Focus criterion: Evidence from Chinese. In Proceedings of the 6th North American conference on Chinese linguistics, ed. Jose Camacho and Lina Choueiri, 51-71. Los Angeles: University of Southern California, GSIL.

Giannakidou, Anastasia, and Lisa L.-S. Cheng. 2006. (In)definiteness, polarity, and the role of wh-morphology in free choice. Journal of Semantics 23: 135-183.

Grohmann, Kleanthes. 2005. Left dislocation in Germanic. In Focus on Germanic typology, ed. W. Abraham, 131-144. Berlin: Akademie Verlag.

Hagstrom, Paul. 1998. Decomposing questions. Ph.D. dissertation, MIT.

Heycock, Caroline. 1994. The internal structure of small clauses. In Proceedings of NELS 25, ed. J. Beckman, 223-238. Amherst: GLSA, University of Massachusetts.

Hinterhölzl, Roland. 2002. Remnant movement and partial deletion. In Dimensions of movement, ed. A. Alexiadou, et al., 127-149. Amsterdam: John Benjamins.

Hoge, Kerstin. 1998. The Yiddish double verb construction. In Oxford working papers in linguistics: Philology and phonetics 2, ed. Willis, 85-97. Oxford: Oxford University, Department of Linguistics.

Höhle, Tilman. 1992. Über verum-fokus im Deutschen [On verum focus in German]. In Informationsstruktur und Grammatik [Information structure and grammar], ed. J. Jacobs, 112-141. Opladen: Westdeutscher Verlag.

Hole, Daniel. 2004. Focus and background marking in Mandarin Chinese: System and theory behind cai, jiu, dou and ye. London and New York: Routledge.

Holmberg, Anders. 1999. Remarks on Holmberg's generalization. Studia Linguistica 53: 1-39.

Huang, C.T. James. 1988. Woo paao de kuai and Chinese phrase structure. Language 64: 274-311.

Huang, Shi-Zhe. 1996. Quantification and predication in Mandarin Chinese: A case study of dou. Ph.D. dissertation, University of Pennsylvania.

Jayaseelan, K.A. 2001. IP-internal topic and focus phrases. Studia Linguistica 55: 39-75.

Kandybowicz, Jason. 2006. Conditions on multiple spell-out and the syntax-phonology interface. Ph.D. dissertation, University of California, Los Angeles.

Koopman, Hilda. 1984. The syntax of verbs. Dordrecht: Foris.

Koopman, Hilda, and Anna Szabolcsi. 2000. Verbal complexes. Cambridge: MIT Press.

Kratzer, Angelika. 1996. Severing the external argument from its verb. In Phrase structure and the lexicon, ed. J. Rooryck, and A. Zaenen, 109-137. Dordrecht: Kluwer.

Krifka, Manfred. 1996. Frameworks for the representation of focus. In Proceedings of the conference on formal grammar at ESSLLI 9, ed. G.-J. M. Kruijff et al., 99-112. Prague: Folli.

Krifka, Manfred. 2006. Association with focus phrases. In The architecture of focus, ed. V. Molnár, and S. Winkler, 105-136. Berlin: Mouton de Gruyter.

Krifka, Manfred. 2007. Basic notions of information structure. In The notions of information structure, ed. C. Féry, et al., 13-55. Potsdam: Universitätsverlag Potsdam.

Landau, Idan. 2006. Chain resolution in Hebrew V(P) fronting. Syntax 9: 32-66.

Lechner, Winfried. 1998. Two kinds of reconstruction. Studia Linguistica 52(3): 276-310.

Lema, José, and María Luisa Rivero. 1989. Long head movement: ECP vs. HMC. In Proceedings of NELS 20, ed. J. Carter et al., 333-347. Amherst: GLSA, University of Massachusetts.

Lipták, Anikó, and Luis Vicente. 2009. Pronominal doubling under VP topicalization. Lingua 119: $560-583$.

Liu, Danqing. 2004. Identical topics: A more characteristic property of topic-prominent languages. Journal of Chinese Linguistics 32: 20-64.

Mahajan, Anoop. 2003. Word order and remnant VP movement. In Word order and scrambling, ed. S. Karimi, 317-337. Oxford: Blackwell.

Marantz, Alec. 1984. On the nature of grammatical relations. Cambridge: MIT Press.

Matushansky, Ora. 2006. Head movement in syntactic theory. Linguistic Inquiry 37: 96-109.

Mikkelsen, Line. 2004. Specifying who: On the structure, meaning, use of specificational copular sentences. Ph.D. dissertation, University of California, Santa Cruz.

Moro, Andrea. 1997. The raising of predicates: Predicate noun phrases and the theory of clause structure. Cambridge: Cambridge University Press.

Nunes, Jairo. 2004. Linearization of chains and sideward movement. Cambridge: MIT Press.

Nunes, Jairo, and Ronice Müller de Quadros. 2006. Duplication of wh- elements in Brazilian Sign Language. In Proceedings of NELS 35, ed. L. Bateman, and C. Ussery, 466-477. Amherst: GLSA. 
Paris, Marie-Claude. 1979. Some aspects of the syntax and semantics of the "lián...ye/dou" construction in Mandarin. Cahiers de linguistique - Asie orientale 5: 47-70.

Paris, Marie-Claude. 1998. Focus operators and types of predication in Mandarin. Cahiers de Linguistique-Asie Orientale 27(2): 139-159.

Pesetsky, David, and Esther Torrego. 2001. T-to-C movement: Causes and consequences. In Ken Hale: A life in language, ed. M. Kenstowicz, 355-426. Cambridge: MIT Press.

Rezac, Milan. 2004. Elements of cyclic syntax. Ph.D. dissertation, University of Toronto.

Rizzi, Luigi. 1997. The fine structure of the left periphery. In Elements of grammar, ed. L. Haegeman, 281-337. Dordrecht: Kluwer.

Roberts, Ian. 2010. Agreement and head movement: Clitics, incorporation, and defective goals. Cambridge: MIT Press.

Shyu, Shu-Ing. 1995. The syntax of focus and topic in Mandarin Chinese. Ph.D. dissertation, University of Southern California.

Shyu, Shu-Ing. 2004. (A)symmetries between Mandarin Chinese Lian-dou and Shenzhi. Journal of Chinese Linguistics 32(1): 71-128.

Soh, Hooi Ling. 1998. Object scrambling in Chinese. Ph.D. dissertation, MIT.

Soh, Hooi-Ling. 2005. Wh-in-situ in Mandarin Chinese. Linguistic Inquiry 36: 143-155.

Svenonius, Peter. 1994. C-selection as feature checking. Studia Linguistica 48: 133-155.

Sybesma, Rint. 1997. The Mandarin VP. Ms., Leiden University.

Tancredi, Christopher. 1990. Syntactic association with focus. In Proceedings of the first meeting of the Formal Linguistic Society of Mid-America, ed., Meyer et al., 289-303. Madison: University of Wisconsin.

Tancredi, Christopher. 2004. Associative operators. Gengo Kenkyu 125: 31-82.

Tang, C.C. Jane. 1994. Conditions on the distribution of postverbal duration and frequency phrases in Chinese revisited. Chinese Languages and Linguistics 2: 641-699.

Toyoshima, Takashi. 2001. Head-to-spec movement and dynamic economy. Ph.D. dissertation, Cornell University.

Travis, Lisa. 1984. Parameters and word order variation. Ph.D. dissertation, MIT.

Tsai, Wei-Tien Dylan. 1994. On economizing the theory of A-bar dependencies. Ph.D. dissertation, MIT. van Riemsdijk, Henk. 1989. Movement and regeneration. In Dialect variation and the theory of grammar, ed. P. Benincá, 105-136. Dordrecht: Foris.

Vicente, Luis. 2007. The syntax of heads and phrases, a study of verb (phrase) fronting. Ph.D. dissertation, Leiden University.

Vicente, Luis. 2009. An alternative to remnant movement for partial predicate fronting. Syntax 12: $158-191$.

von Stechow, Arnim. 1993. Die Aufgaben der Syntax [The objectives of syntax]. In Syntax: Ein internationales Handbuch zeitgenössicher Forschung [Syntax: An international handbook of contemporary research], ed. J. Jacobs et al., 1-88. Berlin: de Gruyter.

Wagner, Michael. 2006. Association by movement: Evidence from NPI licensing. Natural Language Semantics 14: 297-324.

Xiang, Ming. 2008. Plurality, maximality, and scalar inferences: A case study of Mandarin dou. Journal of East Asian Linguistics 7: 227-245. 